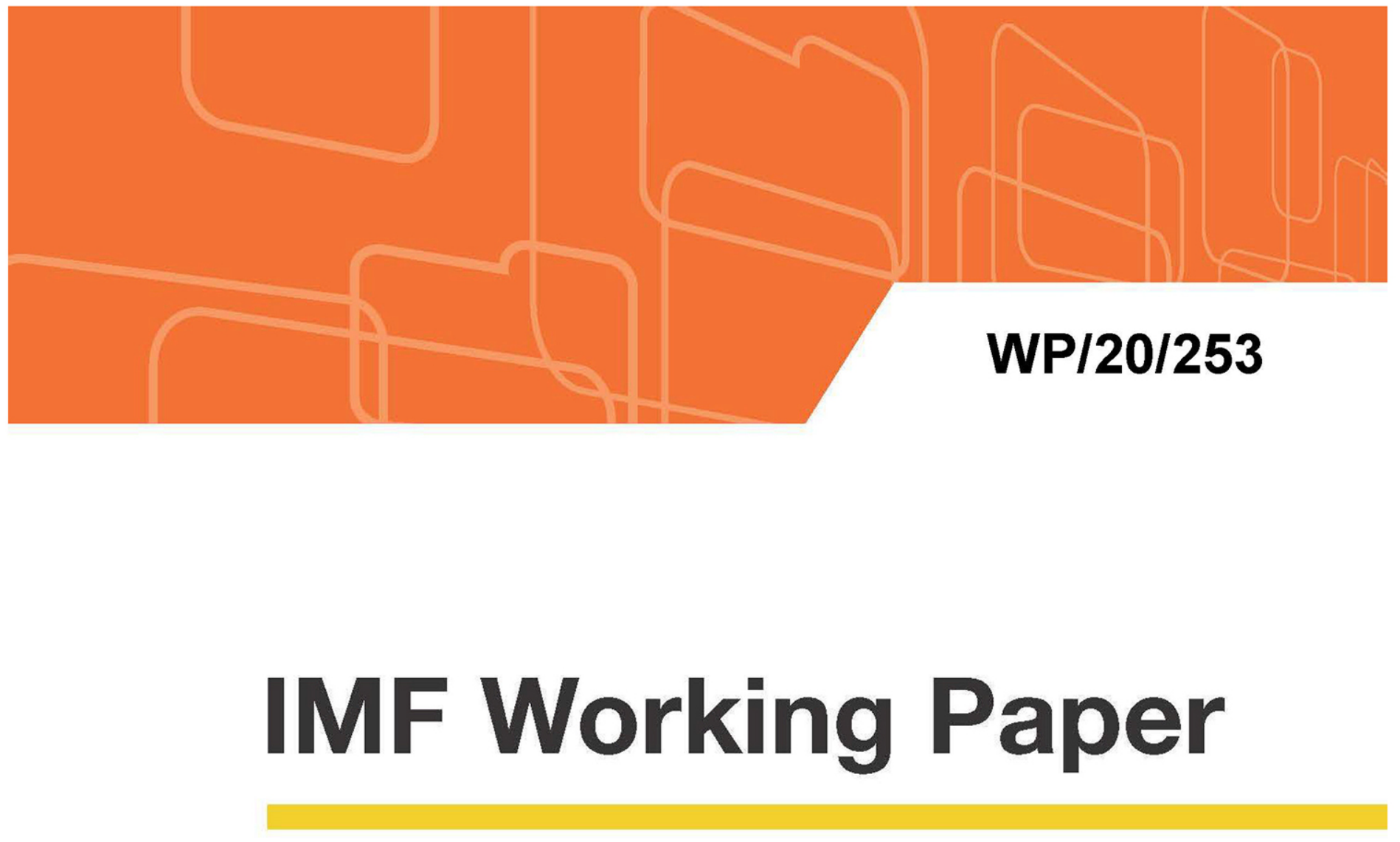

\title{
Energy, Efficiency Gains and Economic Development: When Will Global Energy Demand Saturate?
}

by Christian Bogmans, Lama Kiyasseh, Akito Matsumoto, Andrea Pescatori

IMF Working Papers describe research in progress by the author(s) and are published to elicit comments and to encourage debate. The views expressed in IMF Working Papers are those of the author(s) and do not necessarily represent the views of the IMF, its Executive Board, or IMF management. 




\section{Energy, Efficiency Gains and Economic Development: When Will Global Energy Demand Saturate?}

by Christian Bogmans, Lama Kiyasseh, Akito Matsumoto, Andrea Pescatori

IMF Working Papers describe research in progress by the author(s) and are published to elicit comments and to encourage debate. The views expressed in IMF Working Papers are those of the author(s) and do not necessarily represent the views of the IMF, its Executive Board, or IMF management.

$$
\text { I N TER N A T | O N A L M O N E T A R Y F U N D }
$$




\title{
IMF Working Paper
}

\section{Research Department \\ Energy, Efficiency Gains and Economic Development: When Will Global Energy Demand Saturate?}

\author{
Prepared by Christian Bogmans, Lama Kiyasseh, Akito Matsumoto \\ and Andrea Pescatori ${ }^{1}$ \\ Authorized for distribution by Gian Maria Milesi Ferretti
}

November 2020

\begin{abstract}
IMF Working Papers describe research in progress by the author(s) and are published to elicit comments and to encourage debate. The views expressed in IMF Working Papers are those of the author(s) and do not necessarily represent the views of the IMF, its Executive Board, or IMF management.
\end{abstract}

\section{Abstract}

Not anytime soon. Using a novel dataset covering 127 countries and spanning two centuries, we find evidence for an energy Kuznets curve, with an initial decline of energy demand at low levels of per capita income followed by stages of acceleration and then saturation at high-income levels. Historical trends in energy efficiency have reduced energy demand, globally, by about 1.2 percent per year and have, thus, helped bring forward a plateau in energy demand for high income countries. At middle incomes energy and income move in lockstep. The decline in the manufacturing share of value added, globally, accounted for about 0.2 percentage points of the energy efficiency gains. At the country level, the decline (rise) of the manufacturing sector has reduced (increased) US (China) energy demand by 4.1 (10.7) percent between 1990 and 2017.

JEL Classification Numbers: O11, O13, O44, Q43, Q47

Keywords: Energy demand; economic growth; climate change

Author's E-Mail Address: cbogmans@imf.org; 1kiyasseh@ifc.org; amatsumoto@imf.org; apescatori@imf.org

\footnotetext{
${ }^{1}$ We are grateful to Giovanni Dell'Ariccia, Gian Maria Milesi-Ferretti, Gita Gopinath, Lutz Killian, Thomas Lee, Chris Papageorgiou, Antonio Spilimbergo, Martin Stuermer, Robert J. Vigfusson, and the participants of the 2019 J.P. Morgan Center for Commodities Symposium in Denver, the IMF brown bag seminar, the October 2019 IMF annual meetings, and the 7th International Symposium on Environment and Energy Finance Issues in Paris for helpful comments and suggestions.
} 


\section{INTRODUCTION}

Will global economic growth endanger our planet's capacity to sustain life? Or will higher incomes and human ingenuity be able to preserve it? These questions are particularly relevant today as the debate on climate change mitigation policies intensifies while rising income standards, especially in developing countries, are accompanied by an ever-increasing demand for energy services, which in the early stages of development is frequently satisfied by burning carbon-intensive fossil fuels (i.e., coal, oil, and natural gas). If income and energy are tightly connected then to reduce primary energy's consumption we may have to forfeit income growth. ${ }^{2}$

An analog question - whether environmental concerns could pose limits to growth - was already posed in the context of local pollution more than two decades ago (Grossmann and Krueger 1995 and Stokey 1998). In that context, an inverted U-shaped relation between income and pollution was found which became known as the environmental Kuznets curve (EKC), see Selden and Song (1994). ${ }^{3}$ The empirical evidence for the EKC, however, was later disputed (Harbaugh et al. 2002). Thus, the facts have not unequivocally supported an EKC for local pollutants so far.

Today, however, the most concerning energy externalities are perhaps global (not local) and their effects are less visible and to be felt more prominently by future generations. Stokey (1998)'s rationalization may, thus, not apply to energy emissions. Moreover, even though a transition from high-carbon to low-carbon energy sources will be necessary to reduce carbon emissions, a substantial change in the energy mix at the global level will probably take decades. It is, thus, worth abstracting from the energy mix and ask: what is the historical relationship between economic development and primary energy demand? ${ }^{4}$ Since some high-income countries have seen their energy demand plateau in recent years, it begs the question of whether this phenomenon can be generalized and whether it can help predict a slowdown in energy demand as emerging markets grow. Finally, a better understanding of the relationship between levels of income and energy can help assess the feasibility of climate change targets (such as carbon emissions over GDP) and develop and calibrate integrated assessment models (IAMs) that are used to examine climate policies. ${ }^{5}$ Following Grossman and Krueger (1995), we postulate and test the existence of an energy Kuznets curve that allows for a peak in primary energy sources as income grows. This relationship is proxied by a cubic polynomial in GDP per capita which is the lowest-order polynomial that enables us to capture both a peak in energy demand (i.e. a static saturation

\footnotetext{
${ }^{2}$ If the composition of output and the methods of production were immutable, then energy and economic growth would move in lockstep and externalities from energy generation would be inextricably linked to the scale of global economic activity. Economic growth would have to come to a standstill to prevent environmental disaster. This is what Acemoglu et al. (2012) refer to as the Greenpeace solution.

${ }^{3}$ The environment (e.g., air quality) can be thought of as a normal or luxury good, such that, as income grows countries' desire (and ability) to implement environmental policies to abate pollution increase (Stokey 1998).

${ }^{4}$ The paper will use the term "energy demand" loosely, the energy concept used throughout the paper is total primary energy supply (TPES) which is the overall energy supply made available for use in a country, see Section III.A.

${ }^{5}$ As part of the Paris Agreement on climate change, some countries have committed to reduce their emissions or energy intensity (i.e., the ratio of energy or carbon emissions to GDP). APEC economies pledged to cut their aggregate energy intensity by $45 \%$ from 2005 levels by 2035 while ASEAN countries by $20 \%$ from 2005 levels by 2020 and $30 \%$ by 2025 . Among the countries that have set intensity-based targets are China, India, Malaysia, and U.S. Several other countries have set goals to reduce emissions off a business-as-usual (growth) scenario, including Indonesia, Thailand, and Republic of Korea. If the macro energy (or carbon) elasticity of GDP is or will be less than unity, then energy/emissions intensity will fall in a business-as-usual economic growth scenario.
} 
point) and an inflexion point where the income elasticity of energy demand is the highest. This reduced-form approach has been favored to structural models (see Bhattacharyya 1996 and 2019 for a survey) as being more flexible (i.e., imposing less assumptions), but it requires a sufficiently long history and wide cross-sectional variation. Our dataset starts in 1850 and includes 127 countries in total across various stages of development.

To identify savings in energy consumption beyond and above those associated with income growth, following Griffin and Schulman (2005) and van Benthem and Romani (2009), we add year fixed effects to our empirical specification, and also control for the share of the manufacturing sector in value added. Year fixed effects proxy for omitted variables that move similarly across all countries, especially technology when focusing on low frequencies. Energy saving technologies, by reducing energy demand regardless of the country-specific income level, induce a downward shift, over time, of the energy Kuznets curve. Disentangling the effect of income and technology on energy demand is useful and important, especially in relation to policies in support of R\&D. Utilizing the trend of the year fixed effects to calculate the rate of energy efficiency gains we introduce the concept of dynamic saturation: the level of income at which income growth is perfectly offset by energy efficiency growth, leaving energy demand unchanged, ceteris paribus.

Results strongly support the presence of a Kuznets relationship between log (per capita) energy and $\log$ (per capita) income. This contrasts with results in the literature that find or assume a constant elasticity of energy use with respect to income (Liddle and Huntington 2020, Huntington et al. 2019, Burke et al. 2016, and Csereklyei et al. 2016, among others). Medlock and Soligo (2001) and van Benthem and Romani (2009) found a quadratic relation between energy and income, but the concavity of the relation is unstable because a quadratic relation cannot capture the Kuznets curve's inflexion point where concavity flips. So, the estimates of the concavity depend on whether the sample consists mostly of low-income countries or high-income countries. ${ }^{6}$

The elasticity we find, instead, is low and increasing at low-income levels, peaks at middleincome levels, and declines afterwards. The inflexion point in the energy-income relationship (i.e., the maximum income elasticity) is at about $\$ 10,000$ (2011 USD) below the global per capita income in 2015 of $\$ 15,000$. At that income level the energy's income elasticity is about 1. The peak of the Kuznets curve (i.e., the income level that, statically, determines energy saturation) is high, above $\$ 107,000$. The Kuznets' peak, however, is not precisely estimated because there are not enough observations at very high-income levels. This problem has induced some studies to prefer a linear or quadratic specification to a cubic one (Liddle and Huntington 2020). Instead, this is where the usefulness of the dynamic saturation concept becomes apparent. Since energy efficiency gains have been substantial over the sample, estimated at about 1.2 percent per year, the income necessary to reach dynamic saturation is about $\$ 43,000$, which is already reached by 15 countries in North America,

\footnotetext{
${ }^{6}$ Medlock and Soligo (2001) and van Benthem (2015) estimated an inverted U-shaped relationship for income $\$ 10,000-\$ 40,000$, while van Benthem and Romani (2009) estimated a U-shaped relation for GDP per capita less than $\$ 10,000$. These results, combined, call for a cubic specification.
} 
Europe, and the Asia-Pacific region. ${ }^{7}$ Indeed, Monte Carlo simulations reveal sharp differences in variance and skewness between the two distributions of estimates for the static and dynamic saturation point, with the 90 percent confidence interval of the former $(\$ 81,170$ $162,250)$ being much wider than that of the latter $(\$ 32,970-59,730)$.

Thus, dynamic saturation, a novelty in the literature, can offer a more satisfactory explanation of the energy consumption plateaus observed for advanced economies than earlier work and helps reconcile conflicting results from previous studies. Csereklyei et al. (2016), for example, argues that there is no energy-income decoupling yet and that energy demand (in some sectors of the economy) will continue to increase into the foreseeable future. Van Benthem (2015), instead, estimates that saturation occurs around an income level of $\$ 35,000$, a level already surpassed by many economies. Absolute decoupling of energy and income growth in the near future, however, does not seem plausible on theoretical grounds (for example, service-sector-led economic growth still requires energy), as argued by e.g., Parrique et al. (2019) and Smil $(2017,2019)$. It also cannot explain the tendency for energy consumption, despite its negative trend, to bounce back in years with above-average income growth. Our estimates show that at $\$ 107,000$ per capita absolute energy-income decoupling is still far away. So rather than relying on a negative (or zero) income elasticity, dynamic saturation depends on a combination of factors that allow for a relative decoupling-i.e., a declining but still positive income elasticity and continuous energy efficiency gains that bring about energy saturation at high levels of income.

Historically, efficiency gains have, thus, helped to slow down energy demand globally, thereby reducing the magnitude of the climate change mitigation challenge. An important implication of dynamic saturation is that further declines in energy consumption are by no means guaranteed and will depend on future energy efficiency gains to continue to outpace the effect of income growth on energy consumption. Future efficiency gains seem, thus, critical in the fight against climate change, as global energy demand is unlikely to saturate anytime soon because the income elasticity of energy demand is still close to one for emerging markets.

This paper also contributes to the literature by highlighting the important role played by manufacturing in reducing energy consumption. It finds that while manufacturing offshoring and the global decline of manufacturing are quantitatively relevant forces, neither can wholly explain the decline in energy consumption in advanced economies. Jakob et al. (2012) argue that the decoupling of income growth and energy consumption for advanced economies is in part explained by the weaker relationship between economic growth and manufacturing at higher income levels. Cohen et al. (2017) show that once the impact of trade (and thus manufacturing offshoring, among other factors) is considered, the evidence for a decoupling of growth and emissions in advanced economies becomes weaker. This amounts to comparing the income elasticity of emissions consumption to the income elasticity of emissions production. In contrast to these papers, our work quantifies how the global manufacturing decline lowers the level of income at which countries dynamically saturate,

\footnotetext{
${ }^{7}$ Our results, thus, call for a weak form of energy leapfrogging: latecomers will consume less energy for any given level of income than frontrunners. In contrast, van Benthem (2015) considers and ultimately rejects the hypothesis of a strong form of leapfrogging where latecomers face a lower income elasticity of energy demand than frontrunners.
} 
and to what extent saturation is brought forward in AEs and delayed in EMs due to the offshoring of manufacturing.

Quantitatively, our results indicate that the global decline in the manufacturing share has reduced global energy demand by about 8.7 percent between 1971 and 2017 . This contribution has been stronger for AEs, as manufacturing activities have relocated to EMs. In absence of manufacturing relocation, energy demand in the US would have been 4.1 percent higher, while energy demand in China would have been 10.7 percent lower. Looking forward, however, the scope of both the relocation and reduction of the manufacturing share seems more limited

Our analysis complements existing papers by including novel (historical) data from the following periods: the post global financial crisis era (2009-2017), the golden era of capitalism (1948-1970), the first period of globalization (1850-1913) and the interwar period (1919-1938). We find strong evidence for the Kuznets relationship between income and energy in all of our three historical panels. The point estimates of dynamic saturation from the historical panels are typically larger, at around $\$ 68,000(67,000)$ for the panel $1850-2017$ (1900-2017), though it should be noted they contain fewer countries. Results point to larger efficiency gains in the order of 1.6 (1.3) percent per year for the panel 1850-2017 (19002017) compared to 1.2 percent for the period 1971-2017, perhaps indicating that (some of) the low-hanging energy efficiency fruits have already been harvested by past innovators (Gordon 2012, Bloom et al. 2020).

We also perform a battery of robustness tests. Results are largely unchanged when we exclude one-by-one countries from our main sample but for two exceptions: efficiency gains are smaller (larger) when US (China) is excluded. Adding energy exporters and transition economies to our main sample one at a time does not overthrow the Kuznets relationship between energy and income. It does point, however, to different energy-income dynamics for energy exporters while transition economies introduce a break in efficiency gains in early 1990s. We also tested for a partial adjustment mechanism (see Medlock and Soligo (2001), van Benthem and Romani (2009), van Benthem (2015)), but it does not alter the main results.

Finally, the baseline econometric analysis purposely omits energy prices. In fact, while energy prices (proxied by real oil prices) did fluctuate globally during the sample period, such fluctuations, and their effects on energy demand, are captured by the year fixed effects - this is corroborated by the positive correlation between oil prices and year-fixed effects' deviations from their trend. The omission of energy prices, however, should not affect the estimated trend in efficiency gains because, during the sample period 1971-2017, energy prices do not show any trend. Level differences in energy prices across countries are captured by isolating energy exporters or introducing country fixed effects.

The paper is structured as follows. In the next section we present our conceptual framework and motivating stylized facts about global energy demand and manufacturing. Section III presents our empirical approach to study the relation between energy consumption and income per capita. Our specification allows us to test for static and dynamic saturation points in the relation between energy consumption and income. Section IV describes the 
construction of our energy consumption variable and provides data sources and descriptive statistics for our main panel as well as three novel historical data panels. Section V presents empirical results for our main panel. Section VI shows that qualitatively results hold in a battery of robustness tests; in addition, it repeats the empirical analysis for our three historical panels. Section VII concludes. Additional robustness checks and detailed information on the construction of the historical dataset are reported in several appendices.

\section{CONCEPTUAL FRAMEWORK AND STYLIZED FACTS}

\section{Energy and Durable Goods}

Energy is an essential input in economic systems as most durable goods (i.e., their services) require energy to function. ${ }^{8}$ Energy and durable goods service's consumption are, thus, complements for consumers and producers alike. Hence, for given methods of production, increases in energy demand are driven either by an increase in the number of households and producers that have access to durable goods (i.e., extensive margin) or by a more intensive use of them (i.e., intensive margin). As a country reaches higher incomes, however, both the intensive and extensive margins of durable goods services' consumption can reach a "satiation point" (or offset each other); the associated income level, in turn, is the income that determines a saturation in energy demand. The implication is that, beyond business cycle frequencies, energy demand decouples from income growth and movements in energy prices.

This idea has already been explored in the literature. Farrell (1954) and Bonus (1973) derived an S-shaped logit curve for appliance ownership and, more recently, models in Gertler et al. (2011) and (2016) predict an S-shaped relation between income and electricity demand and household durable good purchases (such as domestic appliances and automobiles). Similarly, Dargay, Gately, and Sommer (2007) and Dargay and Gately (1999) find it for car ownership. ${ }^{9}$ At the aggregate level, it seems plausible that these relations combined would show a maximum elasticity of energy at middle-income levels and a saturation point beyond which energy and income, seemingly, decouple-i.e., they would imply an energy Kuznets curve.

\section{Energy and Structural Change}

The steady increase in global energy demand from 1971 to 2017 by 150 percent (more than 3 percent per year) masks stark dissimilarity between AEs and EMs (Figure 1). The latter, especially China and more recently India, have driven most of the energy growth of the last 15 years while the former's contribution has been minimal leading to a decline in AEs world

\footnotetext{
${ }^{8}$ Energy services are defined as "those functions performed using energy which are means to obtain or facilitate desired end services or states" (Fell 2017). Familiar examples are heating, cooling, lightening, refrigeration, transport, ... Here, however, we do not focus on energy services but on the energy used to provide those services (see Section III.A). The non-energy services demand for fossil fuels stemming mostly from the petrochemical industry is also included in our definition and represents about 6 percent of total primary energy demand.

${ }^{9}$ Dargay, Gately, and Sommer 2007, extending Dargay and Gately (1999) in various directions, use panel data covering 45 countries for the period 1960-2002 to show that the relationship between car ownership and income fits an S-curve with saturation of car ownership at high income levels, which takes places at lower levels for countries with a high population density and high levels of urbanization. Their analysis shows that in combination with declining rates of highway fuel use per vehicle, highway fuel demand is expected to approach saturation for some advanced economies by 2030 .
} 
Figure 1

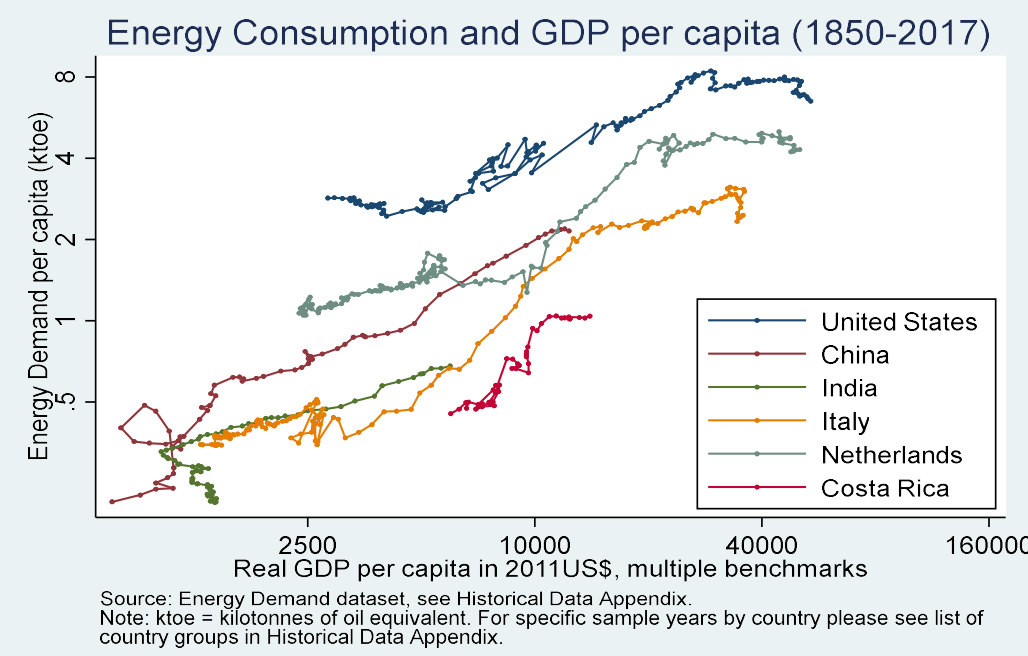

energy consumption shares (Wolfram et al 2012). Some high-income countries seem to have already peaked in terms of per capita and even total energy demand (chart). However, this is not necessarily a proof of saturation, as previously defined, since we must control for per capita income growth and structural change such as changes in the methods of production (i.e., energy efficiency gains) and, for advanced economies, the decline of manufacturing in favor of services.

Indeed, industrial energy demand, which is a complement to services from capital goods, increases rapidly during the early industrialization stage when energy-intensive manufacturing industries expand. As economies develop, the service sector becomes more relevant while the manufacturing sector declines as share of value added and, especially, as share of total employment — given also its relatively higher productivity growth. In addition, since at least the 90s the world has seen a substantial reallocation of manufacturing to EMs.

Figure 2

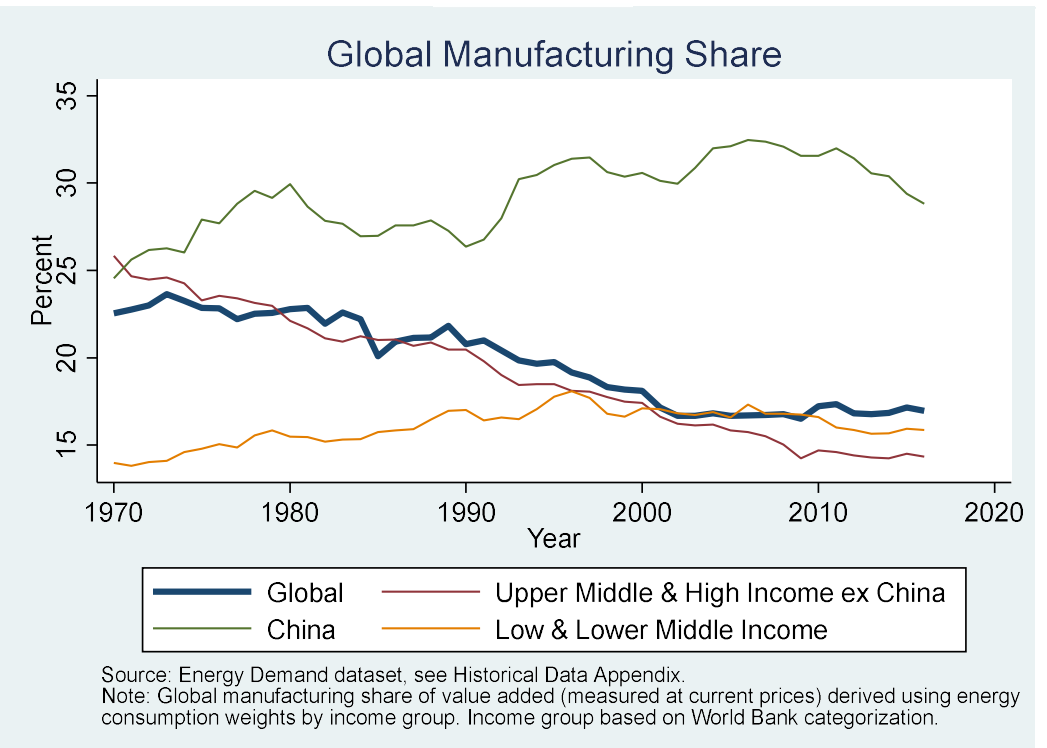


In AEs, the manufacturing share of value added (measured at current prices) has declined steadily since the 1970 s by about 10 percentage points. In part this is due to the decline in the relative price of manufacturing goods (i.e., a relative increase in productivity). Globally, however, the manufacturing share has declined less and only till the beginning of the century as energy-intensive industries moved or re-located from AEs to EMs, especially China (Acemoglu et al 2016, Baily and Bosworth 2014, Fort, Pierce, Schott 2018) (Figure 2). Since the manufacturing sector is relatively energy intensive, these trends probably explain part of the decline in energy per capita observed in advanced economies and the fast energy demand growth of emerging markets.

We, thus, expect a Kuznets curve (i.e., a S-shaped curve) governing the relation between the stage of development and energy demand, like the one found by Grossman and Krueger (1994) for the environment, that is shifted over time by structural changes. Energy saving technologies, in fact, can anticipate actual saturation by shifting down the energy-income curve because the same economic activities (such as heating, cooling, transports, ...) require less energy while economies with a higher manufacturing share require relatively more energy. ${ }^{10}$ Energy efficiency gains can come about through various mechanisms, including increased thermal efficiency of fossil fuel power plants and improved fuel economy of internal combustion engines. The next sections will offer a quantification of the Kuznets curve.

\section{EMPIRICAL ANALYSIS}

Using an unbalanced panel dataset of low-, medium-, and high-income countries, we study the relation between energy demand and income, isolating the role of the manufacturing sector and controlling for population density (i.e., population and land area). Country fixed effects are introduced for robustness to control for country-specific factors that could explain different energy needs (such as latitude). Furthermore, we use time dummies to capture energy efficiency gains, fluctuations in global energy demand that are not fully captured by income, and movements in energy prices. However, since the relative price of energy is mean reverting in our sample, we interpret the trend component of the time dummies as energy efficiency. ${ }^{11} 12$

Our empirical approach generalizes earlier contributions to the literature on energy demand, including Medlock and Soligo (2001) and van Benthem (2015) and it follows the seminal work of Grossman and Krueger (1995). ${ }^{13}$ In particular, we estimate the following

\footnotetext{
${ }^{10}$ Energy saving technology is not limited to same-good improvements such as replacing fuel inefficient with efficient cars or incandescent with LED light bulbs. It includes higher energy conversion efficiency and the adoption of new products and services that can save energy such as communication via email or remote working arrangements.

${ }^{11}$ Liddle and Huntington (2020), exploiting a novel country-level dataset on end-use prices, does not find a quantitatively relevant effect of energy prices on the estimates of income elasticities.

${ }^{12}$ There is long-standing debate in resource economics on whether energy efficiency implies a reduction in energy demand. Jevons (1865) asserts: "[I]t is wholly a confusion of ideas to suppose that the economical use of fuel is equivalent to a diminished consumption. The very contrary is the truth $[\ldots]$ Every improvement of the engine when effected will only accelerate anew the consumption of coal." Most recent studies, however, do not find the Jevons' effect—instead, energy demand declines, all else equal, as energy efficiency improves (Greening, Greene, and Difiglio 2000; Sorrell 2009).

${ }^{13}$ Holtz-Eakin and Selden (1995) is a closely related empirical study on the relationship between economic development and CO2 emissions, but in contrast to Grossman and Krueger (1995) and our work their empirical specification does not include a cubic income term.
} 
specification relating (log of) primary energy demand $E$ to (log of) population, pop, a $3^{\text {rd }}$ order polynomial in (log) income per capita, $y$, the manufacturing share and a set of control variables:

$$
E_{i t}=\beta_{0}+\beta_{p} \text { pop }_{i t}+\beta_{1} y_{i t}+\beta_{2}\left(y_{i t}\right)^{2}+\beta_{3}\left(y_{i t}\right)^{3}+\lambda_{t}+\beta_{A} A_{i}+\beta_{m} m_{i t}+\varepsilon_{i t}(1)
$$

where $\lambda_{t}$ are year fixed effects, $A_{i}$ is a set of control variables including country fixed effects or $(\log )$ land area; $m_{i t}$ is a measure of the manufacturing share in value added (measured at current prices), and the indices $i$ and $t$ refer to countries and years, respectively. In the baseline regression, the manufacturing share is in deviation from the global share and orthogonalized with respect to the rest of the regressors. To gain insights into its role, the manufacturing share is also introduced just in deviation from the global share and as is.

The IEA baseline sample is annual and spans from 1971 to 2017 covering 97 countries (excluding energy exporters and transition economies) and two major energy price cycles. The historical dataset starts in 1850, but it features fewer countries (its results are presented in Section VI). In the Robustness section we introduce energy exporters and transition economies one by one to our main sample of 97 countries.

Since small countries can have very specific energy issues (especially in terms of initial energy endowment or energy needs) we rely on weighted least squares (WLS) as it is more unlikely that these idiosyncrasies play a major role in large countries. Also, large countries will drive future global emissions and energy demand, by giving large countries more weight we can speak more directly to climate-related questions. WLS are preferred to country fixed effects (FE) because the latter do not let us exploit persistent cross-sectional income differences. The combined used of WLS and FE is, instead, problematic (see Section IV).

The above specification allows us to test for a peak (saturation), a trough (graduation), and an inflexion point (max elasticity) in the relationship between energy and income. The $(\log )$ per capita income levels that define static saturation and graduation from biomass, $y_{k}$ with $k=$ $s, g$, where $s(g)$ stands for saturation (graduation), solves the following quadratic equation

$$
\delta_{1}+2 \delta_{2} y_{k}+3 y_{k}^{2}=0
$$

where $\delta_{i}=\beta_{i} / \beta_{3}$ for $i=1,2$ and $\beta_{3} \neq 0$. The inflexion point (i.e., maximum elasticity) is given by $-\delta_{2} / 3 .{ }^{14}$ The special case of $\beta_{2}=\beta_{3}=0$ and $\beta_{1}=\beta_{p}$ corresponds to the case where log energy demand scales up proportionally to $\log$ GDP. The (log) saturation and graduation points are defined as

In addition, the empirical panel used by Holtz-Eakin and Selden (1995) spans the period between 1951 and 1986 , which implies that three decades of recent data are unexamined.

${ }^{14}$ The coefficient $\beta_{3}<0$ is necessary to have a graduation point lower than saturation, while $\delta_{2}^{2}>3 \delta_{1}$ guarantees the existence of a saturation point. 


$$
y_{k}=\left(-\delta_{2}+/-\sqrt{\delta_{2}^{2}-3 \delta_{1}}\right) / 3
$$

The (log) dynamic saturation point, $\mathrm{z}$, is calculated by total differencing equation (1) with respect to time and, thus, solves the following equation

$$
\left(\beta_{1}+2 \beta_{2} z+3 \beta_{3} z^{2}\right) \dot{y}+\dot{\lambda}+\beta_{p} \dot{p}+\beta_{m} \dot{m}=0
$$

Where $\dot{y}$ is income growth, $\dot{\lambda}$ is the annual energy efficiency loss, $\dot{m}$ is the change in the manufacturing share, and $\dot{p}$ is population growth. Assuming a constant manufacturing share, $\dot{m}=0$, the solution takes the same form of (2) but with a modified $\delta_{1}$

where

$$
z=\left(-\delta_{2}+\sqrt{\delta_{2}^{2}-3 \tilde{\delta}_{1}}\right) / 3
$$

$$
\tilde{\delta}_{1} \stackrel{\text { def }}{=} \delta_{1}+\left(\dot{\lambda}+\beta_{p} \dot{p}\right) /\left(\beta_{3} \dot{y}\right)
$$

If $\delta_{2}^{2}>3 \delta_{1}$ (i.e., given a static saturation point), as far as $\dot{\lambda}<\beta_{p} \dot{p}$ and $\beta_{3} \dot{y}>0$, dynamic saturation exists and is lower than its static counterpart, $z<y_{s}$. The intuition is simple, energy saving (i.e., $\dot{\lambda}<0$ ) shifts down the Kuznets curve while income growth represents the speed at which a point moves over the curve. When the two opposite forces offset each other, we have dynamic saturation in energy demand. ${ }^{15}$ In absence of energy savings and with constant population, static and dynamic saturation coincide. Income growth, however, is a "free parameter". We discipline its choice by estimating a beta-convergence relation between growth and the level of income, $\dot{y}=\hat{a}+\hat{b} y$, over the sample (Barro and Sala-i-Martin $(2004)) .{ }^{16}$

The static saturation point may be hard to estimate as it probably implies an income level that few or no countries have reached yet. Since $z<y_{s}$, however, it is more likely that some countries are at or close to the dynamic saturation point. We will exploit this consideration later and analyze the estimated covariances among coefficients that enter the saturation point's calculation.

\section{Data}

For our main analysis we constructed an annual panel from 1971 to 2017 . This panel is slightly unbalanced, with the number of countries increasing from 88 in 1971 to 97 in 2008 and thereafter. ${ }^{17}$ In addition, we constructed three historical balanced panels: the first and the longest, Group 1, covers 1850 to 2017 (11 countries), Group 2 covers 1900 to 2017 (31

\footnotetext{
${ }^{15}$ Geometrically, in a (log) energy-income plane, dynamic saturation equates the efficiency vector (i.e., how fast the curve is shifting down) with the vector tangential to the s-curve whose length is given by income growth (i.e., how fast a country is traveling on the curve). If the determinant, $\delta_{2}^{2}-3 \tilde{\delta}_{1}$, is negative or infinite, for example when income growth is zero, dynamic saturation is not well defined as there is no income level that can guarantee zero energy growth.

${ }^{16}$ In this case, the dynamic saturation point is the solution of a $3^{\text {rd }}$ order polynomial as $\dot{y}=\hat{a}+\hat{b} z$.

${ }^{17}$ Energy data in our main panel is available for 108 countries, but missing observations for independent variables, especially for manufacturing, reduces the number of countries in our main empirical analysis to 97.
} 
countries), and Group 3 covers 1950 to 2017 (65 countries). By digitalizing and bringing together various historical data sources, our main data contribution is to expand the number of observations in the period 1850-1949 and 1950-1970, which respectively contain 2126 and 2086 observations. To the best of our knowledge, our historical energy panel dataset contains significantly more observations than previous work in the literature. ${ }^{18}$

Throughout the paper, energy demand reflects the total primary energy supply (TPES), which measures the total amount of energy that is made available to domestic end-users in the economy (in million tonnes of oil equivalent, MTOE). In contrast to total final consumption (TFC, used, for example, in van Benthem 2015 and Csereklyei et al. 2016), TPES captures energy efficiency gains along the entire supply chain due to its upstream character. ${ }^{19}$ TPES is also more pertinent than TFC when studying environmental and climate related questions.

The global coverage of energy consumption, GDP per capita, population, and the manufacturing share increases slowly and steadily between 1850 and 1949, and then expands greatly from 1950 onwards. Manufacturing data is an exception and doesn't cover much more countries until the 1970s, a jump that coincides with the publication of the UN national accounts data.

Table 1 presents descriptive statistics for the four panels. The raw data shows, perhaps not surprisingly, that the range of values as well as the standard deviation for energy consumption per capita, GDP per capita, and the manufacturing share are larger or at least as large in our main panel of 97 countries than in our historical panels. The standard deviation of GDP and the range of values for energy consumption growth (log-diff) are smaller in Group 1 and increase with the extension of the cross-section, highlighting its importance. The relative importance of the cross-section compared to the time dimension, can in part be attributed to the fact that the United States and many other advanced economies had already reached (upper-)middle-income status between 1850-1900. Also, members of Group 1 show a high degree of co-movement.

\footnotetext{
${ }^{18}$ By comparison, energy consumption data in van Benthem (2015) spans 1960-2006 and 1970-2006 for OECD and non-OECD countries respectively, while data in Csereklyei et al. (2016) covers the period 1970-2010. Csereklyei et al. (2016) also analyze a historical panel of 11 countries between 1800 and 2010 that is comparable to our Group 1 historical panel, but they don't have data that is comparable to our Group 2 and Group 3 panels.

${ }^{19}$ Electricity is not a primary energy supply since it is generated from fossil fuels, mainly from coal and natural gas, nuclear, hydro, solar photovoltaic, wind, geothermal, biomass and waste, and a few other sources. In the absence of conversion efficiency gains, an increase of electricity generation implies an increase of demand for these energy sources. There is, however, potential for efficiency improvements when primary energy sources are converted into electricity and heat in thermal power plants (=thermal efficiency) and when end-use appliances including TVs, refrigerators, iPads, and mobile phones convert energy into energy services (=end-use efficiency).
} 
Table 1: Descriptive Statistics

\begin{tabular}{|c|c|c|c|c|c|c|c|c|c|c|}
\hline \multirow[b]{2}{*}{ Label } & \multicolumn{5}{|c|}{ All Countries (1971-2017) } & \multicolumn{5}{|c|}{ Group 1 (1850-2017) } \\
\hline & Obs & Mean & Std. Dev. & Min & $\operatorname{Max}$ & Obs & Mean & Std. Dev. & Min & $\operatorname{Max}$ \\
\hline Energy consumption per capita & 4,388 & -6.80 & 1.06 & -9.46 & -4.01 & 1,574 & -6.34 & 0.85 & -8.61 & -4.78 \\
\hline Energy consumption per capita (log diff) & 4,383 & 0.01 & 0.07 & -0.78 & 0.63 & 1,555 & 0.01 & 0.07 & -0.48 & 0.50 \\
\hline GDP per capita (p.c.) & 4,388 & 8.89 & 1.14 & 5.92 & 11.31 & 1,574 & 9.01 & 0.98 & 7.23 & 11.31 \\
\hline GDP per capita (log diff) & 4,385 & 0.02 & 0.07 & -0.85 & 0.60 & 1,570 & 0.02 & 0.05 & -0.23 & 0.51 \\
\hline$(\text { GDP p.c. })^{\wedge 2}$ & 4,388 & 80.38 & 20.25 & 35.07 & 128.00 & 1,574 & 82.06 & 17.99 & 52.34 & 128.00 \\
\hline$(G D P \text { p.c. })^{\wedge} 3$ & 4,388 & 737.82 & 273.15 & 207.64 & $1,448.09$ & 1,574 & 756.63 & 250.61 & 378.70 & $1,448.09$ \\
\hline Area & 4,388 & 12.24 & 2.11 & 5.77 & 16.05 & 1,574 & 12.36 & 1.65 & 10.32 & 16.03 \\
\hline Manufacturing Share & 4,314 & 16.69 & 6.59 & 0.30 & 38.70 & 1,468 & 20.44 & 6.74 & 7.36 & 43.98 \\
\hline Manufacturing Share (dev.) & 4,314 & -3.42 & 6.38 & -23.48 & 19.29 & 1,468 & -0.05 & 5.98 & -10.20 & 24.46 \\
\hline \multirow[t]{2}{*}{ Manufacturing Share (ort) } & 4,314 & -4.76 & 6.78 & -28.03 & 24.78 & 1,468 & -1.74 & 5.67 & -14.09 & 21.81 \\
\hline & \multicolumn{5}{|c|}{ Group 2 (1900-2017) } & \multicolumn{5}{|c|}{ Group 3 (1950-2017) } \\
\hline Label & Obs & Mean & Std. Dev. & Min & Max & Obs & Mean & Std. Dev. & Min & Max \\
\hline Energy consumption per capita & 2,867 & -6.47 & 0.95 & -8.66 & -4.76 & 3,826 & -6.75 & 1.03 & -9.03 & -4.39 \\
\hline Energy consumption per capita (log diff) & 2,845 & 0.01 & 0.07 & -0.54 & 0.58 & 3,795 & 0.02 & 0.06 & -1.29 & 0.58 \\
\hline GDP per capita (p.c.) & 2,867 & 9.10 & 1.01 & 6.40 & 11.31 & 3,826 & 8.89 & 1.18 & 5.92 & 11.31 \\
\hline GDP per capita (log diff) & 2,866 & 0.02 & 0.05 & -0.68 & 0.51 & 3,807 & 0.03 & 0.05 & -0.37 & 0.34 \\
\hline$(\text { GDP p.c. })^{\wedge} 2$ & 2,867 & 83.88 & 18.19 & 41.01 & 128.00 & 3,826 & 80.38 & 20.68 & 35.07 & 128.00 \\
\hline$(G D P \text { p.c. })^{\wedge} 3$ & 2,867 & 781.82 & 248.94 & 262.58 & $1,448.09$ & 3,826 & 738.69 & 277.10 & 207.64 & $1,448.09$ \\
\hline Area & 2,867 & 13.12 & 1.76 & 10.32 & 16.03 & 3,826 & 12.92 & 1.83 & 6.93 & 16.05 \\
\hline Manufacturing Share & 2,444 & 20.28 & 6.03 & 5.69 & 39.14 & 3,240 & 18.86 & 6.76 & 1.08 & 40.75 \\
\hline Manufacturing Share (dev.) & 2,444 & -0.94 & 5.44 & -20.14 & 16.03 & 3,240 & -2.21 & 6.27 & -20.14 & 19.29 \\
\hline Manufacturing Share (ort) & 2,444 & -2.56 & 5.16 & -19.50 & 11.85 & 3,240 & -3.09 & 6.38 & -23.45 & 25.66 \\
\hline
\end{tabular}

Sources: Maddison; Mitchell; World Bank; United Nations; and IMF staff calculations

Note: See country table for further details on countries included in each group. Obs $=$ observations, Std. Dev. $=$ standard deviation. All variables in logarithmic scale except the manufacturing variables. Manufacturing Share (dev.) is in deviation from its global average, while Manufacturing Share (ort.) has been orthogonalized to a third order income p.c. polynomial. 


\title{
IV. EMPIRICAL RESULTS
}

Results strongly support the presence of a Kuznets curve where the energy demand elasticity to income increases at low-income levels, peaks at middle-income levels at around one, and declines toward zero at high-income levels. A constant income elasticity of energy demand is rejected by the data (Table 2 and Figure 3). ${ }^{20}$ This result is in contrast with other results in the literature that suggest or impose a constant income elasticity (such as Burke et al 2016 and Csereklyei et al 2016, among others).

Figure 3

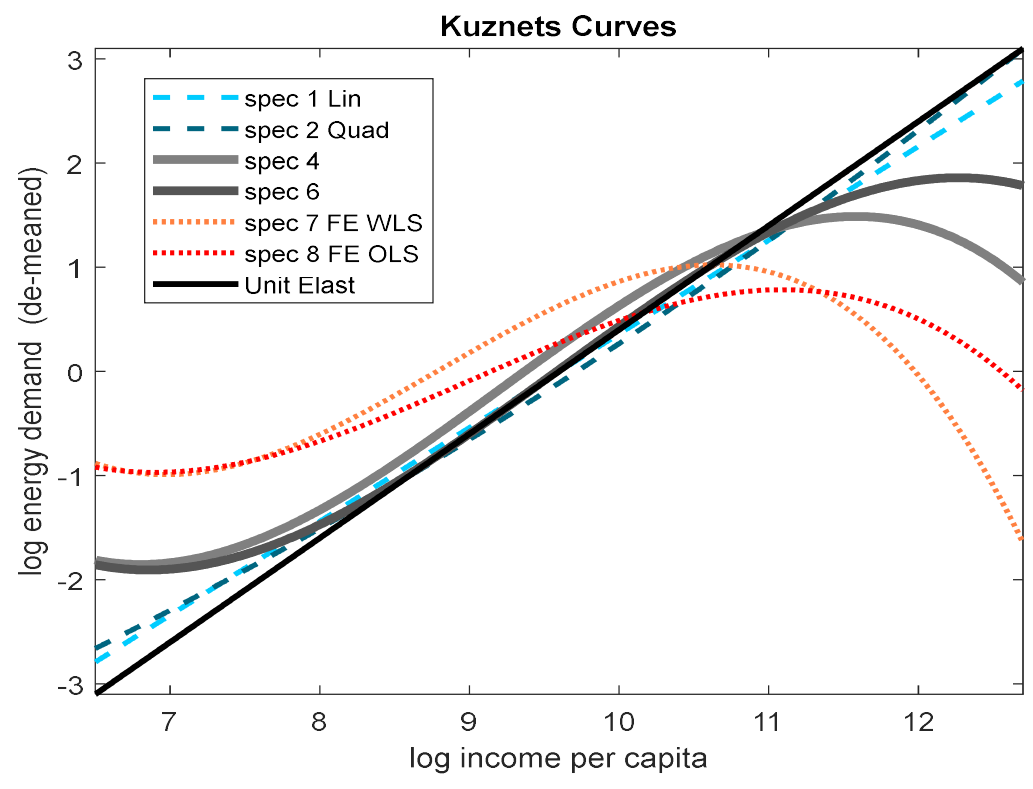

\begin{abstract}
Source: Energy Demand dataset, see Historical Data Appendix.
Note: The figure shows demeaned Kuznets curves estimated in Table 2. Dashed blue and black lines are the linear and quadratic specifications, respectably. Dotted yellow and red lines are country fixed effects specifications using WLS and OLD, respectively. The solid grey line is our baseline specification while the solid black line is specification 6 where manufacturing is introduced as is. Black line is unitary elasticity.
\end{abstract}

In the baseline specification, (4), the manufacturing share has been orthogonalized to the rest of other explanatory variables. In this way, time dummies and income still subsume the role of manufacturing across time and stages of development while its coefficient correctly represents the semi-elasticity of energy demand to the manufacturing share (Table 2, compare specifications 4 and 6).

A trend line fits very well the evolution of time dummies supporting the view that their low frequency movement is mostly capturing a global shift in technologies and methods of production rather than common changes in energy prices, taxes or subsidies, regulation, or other global factors (Figure 4). Indeed, cyclical movements in energy efficiency-i.e. deviations from the trend line-are negatively correlated to (real) oil price levels and

${ }^{20}$ Coefficients of the polynomial (including the constant) should not be analyzed in isolation as they show a very strong correlation. A graphic representation is, thus, useful. 
positively correlated to GDP growth (see Appendix C). Moreover, we reject the ADF unit root test for real oil prices at the 5 percent level in the 1971-2017 sample (real oil prices in 2017 are about as they were in 1975 and about equal to the 1971-1981 average). Hence, trend efficiency gains must represent the average adoption, across countries and over the medium term, of energy efficient technologies - controlling for the stage of economic development. These gains substantially reduced energy demand over the sample period, by about 1.2 percent per year in the baseline specification (Table 2, specification 4), and are strongly significant across specifications (except when country fixed effects are used, see discussion below). ${ }^{21}$ Comparing specification 5 and 6 we can identify the contribution of manufacturing to efficiency gains. The global decline in the manufacturing sector share has contributed about 0.2 percentage points to energy efficiency gains, mostly between the $1980 \mathrm{~s}$ and $1990 \mathrm{~s}$ (Table 2, Figure 2, and Figure 4).

\section{Energy Efficiency}

Figure 4

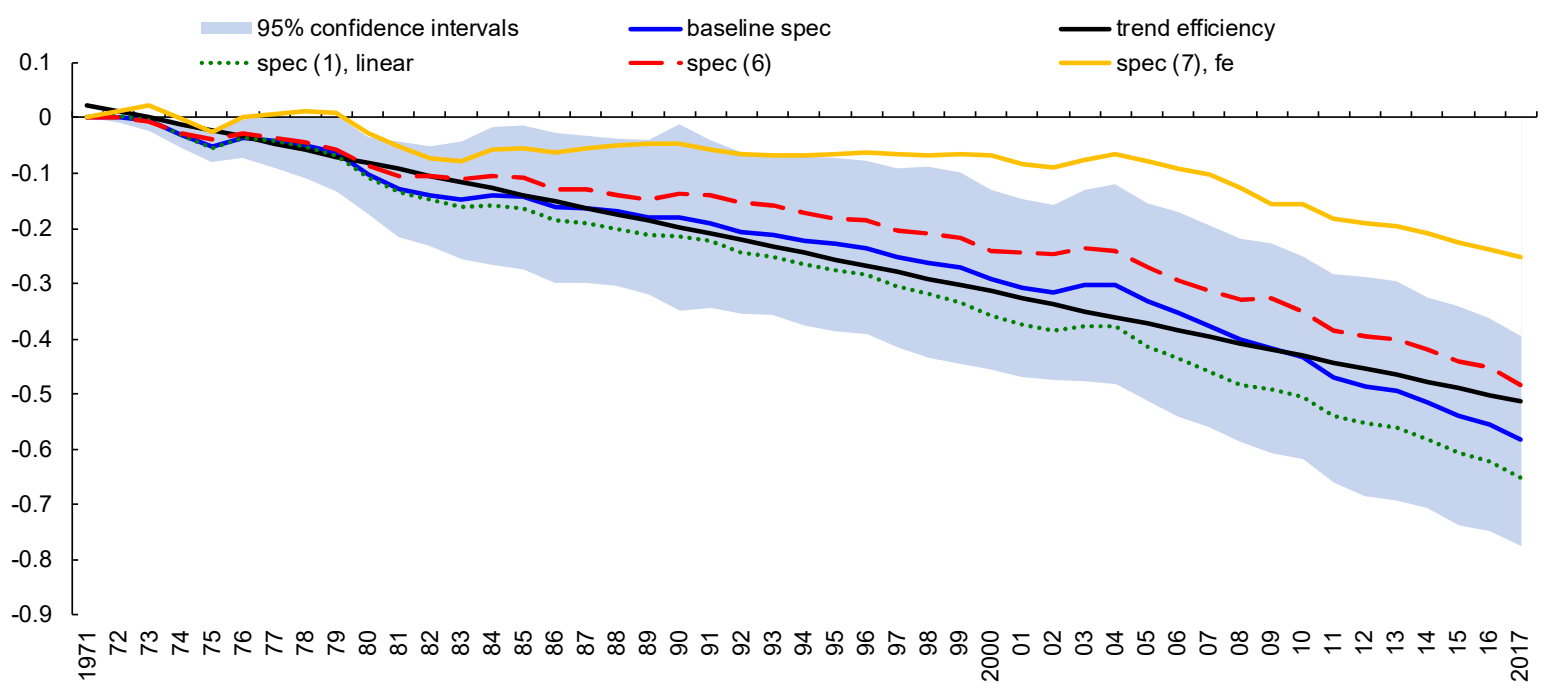

Source: Energy Demand dataset, see Historical Data Appendix.

Note: The blue line represents the time fixed effects estimated in regression (4), which is the baseline, with 95 percent confidence intervals (blue dashed lines). The black line is a linear trend estimated for the period 1971-1989 (1992-2017). Other time fixed effects shown map the specifications from Table $2 ; \mathrm{fe}=$ country fixed effects; $\mathrm{spec}=$ specification

\footnotetext{
${ }^{21}$ As a matter of comparison, over the same period the US TFP growth was about 0.8 . See Fernald (2014).
} 
Table 2: Primary Energy Demand Determinants by Specification

\begin{tabular}{|c|c|c|c|c|c|c|c|c|}
\hline & $(1)$ & $(2)$ & (3) & (4) & (5) & (6) & $(7)$ & $(8)$ \\
\hline Population & $\begin{array}{l}0.989^{\star * \star} \\
(0.0358)\end{array}$ & $\begin{array}{l}0.992^{\star \star \star} \\
(0.0368)\end{array}$ & $\begin{array}{l}0.996^{\star \star \star} \\
(0.0356)\end{array}$ & $\begin{array}{l}0.996^{\star \star \star} \\
(0.0302)\end{array}$ & $\begin{array}{l}0.946^{\star * *} \\
(0.0291)\end{array}$ & $\begin{array}{l}0.946^{\star * *} \\
(0.0291)\end{array}$ & $\begin{array}{l}1.196^{\star \star *} \\
(0.130)\end{array}$ & $\begin{array}{l}1.215^{\star \star *} \\
(0.226)\end{array}$ \\
\hline GDP per capita (p.c.) & $\begin{array}{l}0.900^{* * *} \\
(0.0262)\end{array}$ & $\begin{array}{l}0.272 \\
(0.550)\end{array}$ & $\begin{array}{l}-14.47^{\star * *} \\
(2.479)\end{array}$ & $\begin{array}{l}-14.47^{\star * *} \\
(2.790)\end{array}$ & $\begin{array}{l}-11.99^{* * *} \\
(2.796)\end{array}$ & $\begin{array}{l}-11.99^{* * *} \\
(2.796)\end{array}$ & $\begin{array}{l}-18.32^{* * *} \\
(1.803)\end{array}$ & $\begin{array}{l}-10.90^{\star * *} \\
(2.327)\end{array}$ \\
\hline$(G D P \text { p.c. })^{\wedge} 2$ & & $\begin{array}{l}0.0342 \\
(0.0304)\end{array}$ & $\begin{array}{l}1.688^{\star * *} \\
(0.281)\end{array}$ & $\begin{array}{l}1.688^{\star * *} \\
(0.311)\end{array}$ & $\begin{array}{l}1.363^{* \star *} \\
(0.314)\end{array}$ & $\begin{array}{l}1.363^{\star \star *} \\
(0.314)\end{array}$ & $\begin{array}{l}2.175^{\star \star *} \\
(0.201)\end{array}$ & $\begin{array}{l}1.281^{* \star *} \\
(0.268)\end{array}$ \\
\hline$(G D P \text { p.c. })^{\wedge} 3$ & & & $\begin{array}{l}-0.0612^{* * *} \\
(0.0106)\end{array}$ & $\begin{array}{l}-0.0612^{* \star *} \\
(0.0115)\end{array}$ & $\begin{array}{l}-0.0475^{\star \star *} \\
(0.0117)\end{array}$ & $\begin{array}{l}-0.0475^{\star * *} \\
(0.0117)\end{array}$ & $\begin{array}{l}-0.0824^{* * *} \\
(0.00744)\end{array}$ & $\begin{array}{l}-0.0475^{\star * *} \\
(0.0103)\end{array}$ \\
\hline Area & $\begin{array}{l}0.101^{\text {***}} \\
(0.0277)\end{array}$ & $\begin{array}{l}0.0970^{* * *} \\
(0.0282)\end{array}$ & 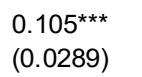 & $\begin{array}{l}0.105^{\star * *} \\
(0.0269)\end{array}$ & $\begin{array}{l}0.126^{* * *} \\
(0.0260)\end{array}$ & $\begin{array}{l}0.126^{\star * *} \\
(0.0260)\end{array}$ & & \\
\hline Energy Efficiency (a.r., \%) & $\begin{array}{l}-1.382^{\star * *} \\
(0.2125)\end{array}$ & $\begin{array}{l}-1.393^{\star \star *} \\
(0.2468)\end{array}$ & $\begin{array}{l}-1.240^{\star \star *} \\
(0.1823)\end{array}$ & $\begin{array}{l}-1.240^{\star \star *} \\
(0.2034)\end{array}$ & $\begin{array}{l}-1.244^{\star * *} \\
(0.2031)\end{array}$ & $\begin{array}{l}-1.031^{\star \star *} \\
(0.2276)\end{array}$ & $\begin{array}{r}-0.534 \\
(0.2765)\end{array}$ & $\begin{array}{r}-0.231 \\
(0.4829)\end{array}$ \\
\hline Manufacturing Share & & & & & & $\begin{array}{l}0.0160^{* * *} \\
(0.00457)\end{array}$ & & \\
\hline Manufacturing Share (ort.) & & & & $\begin{array}{l}0.0160^{\star \star *} \\
(0.00457)\end{array}$ & & & $\begin{array}{l}0.0187^{\star \star \star} \\
(0.00379)\end{array}$ & $\begin{array}{l}0.0139^{\star *} \\
(0.00466)\end{array}$ \\
\hline Manufacturing Share (dev.) & & & & & $\begin{array}{l}0.0160^{\star * *} \\
(0.00457)\end{array}$ & & & \\
\hline Constant & $\begin{array}{l}-15.63^{* * *} \\
(0.322)\end{array}$ & $\begin{array}{l}-12.75^{\star * *} \\
(2.626)\end{array}$ & $\begin{array}{l}30.34^{* * *} \\
(7.273)\end{array}$ & $\begin{array}{l}30.34^{\star * *} \\
(8.246)\end{array}$ & $\begin{array}{l}24.56^{\star \star} \\
(8.231)\end{array}$ & $\begin{array}{l}24.20^{\star *} \\
(8.241)\end{array}$ & $\begin{array}{l}40.67^{\star * *} \\
(5.440)\end{array}$ & $\begin{array}{l}20.56^{\star *} \\
(7.606)\end{array}$ \\
\hline Observations & 4382 & 4382 & 4382 & 4382 & 4382 & 4382 & 4382 & 4382 \\
\hline \# of countries & 97 & 97 & 97 & 97 & 97 & 97 & 97 & 97 \\
\hline $\begin{array}{l}\text { R-sq } \\
\text { model }\end{array}$ & $\begin{array}{l}0.97 \\
\text { wls }\end{array}$ & $\begin{array}{l}0.97 \\
\text { wls }\end{array}$ & $\begin{array}{l}0.98 \\
\text { wls }\end{array}$ & $\begin{array}{l}0.98 \\
\text { wls }\end{array}$ & $\begin{array}{l}0.98 \\
\text { wls }\end{array}$ & $\begin{array}{l}0.98 \\
\text { wls }\end{array}$ & $\begin{array}{l}1.00 \\
\text { wls fe }\end{array}$ & $\begin{array}{l}0.99 \\
\text { ols fe }\end{array}$ \\
\hline \multicolumn{9}{|c|}{$\begin{array}{l}\text { Sources: Maddison; Mitchell; World Bank; United Nations; and IMF staff calculations } \\
\text { Note: Based on years 1971-2017. Robust standard errors clustered at the country level in parentheses. All variables in logarithmic } \\
\text { scale except "manufacturing share" and "year". Average elasticity is calculated at } 15,0002011 \text { international USD. All regressions } \\
\text { have time fixed effects; fe = country fixed effects; ols = ordinary least squares; wls = weighted least squares. Manufacturing Share } \\
\text { (dev.) is in deviation from its global average, while Manufacturing Share (ort.) has been orthogonalized to a third order income p.c. } \\
{ }^{*} p<0.05,{ }^{* *} p<0.01,{ }^{* * *} p<0.001\end{array}$} \\
\hline
\end{tabular}


Figure 5

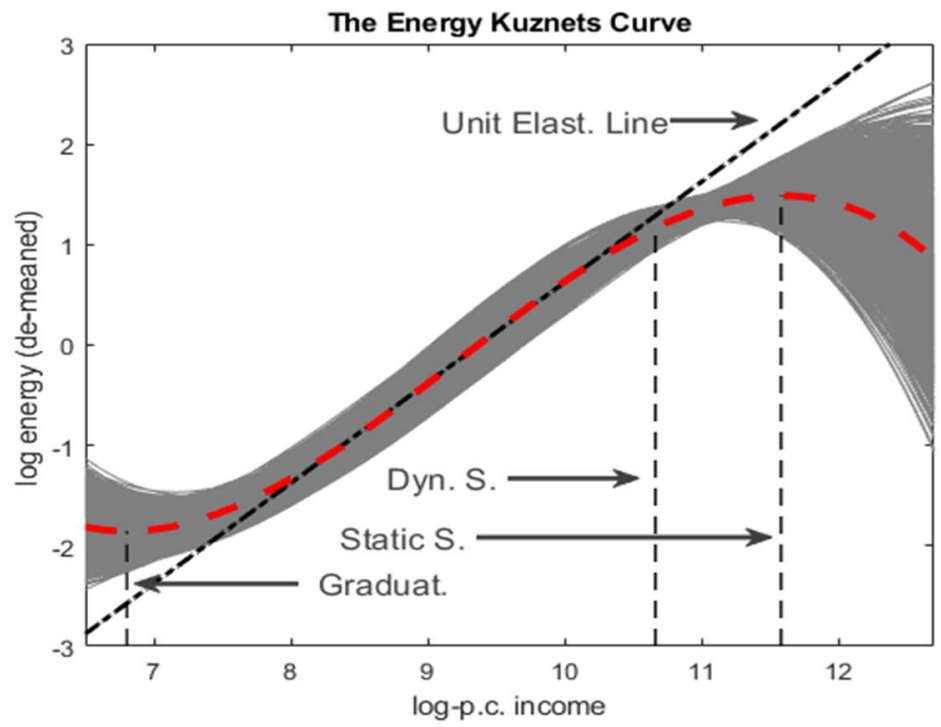

Source: Energy Demand dataset, see Historical Data Appendix. Note: The figure shows 1000 Monte Carlo draws of demeaned Kuznets curves for specification 4 of Table 2. The dash red line is the point estimate Kuznet curve. Dot dashed line is the unitary elasticity. The dynamic saturation vertical bar is calculated using the average efficiency gains estimated for specification 4 and income growth as described in Section III.

A parsimonious linear specification can be appealing, however, the estimated income elasticity, 0.9, is lower than in the baseline specification because it must strike a balance between high- and medium-income countries' elasticities (Table 2). In fact, for high-income countries, higher estimated elasticities would require unreasonably high efficiency gains to square the data (see Figure 7 upper panel). Adding a quadratic income term does not help, as it tries to capture both the increase in income elasticities at middle-income levels and the flattening of the relation at higher income levels. This struggle makes quadratic estimates not significant. The cubic specification, instead, solves the above problem increasing the income elasticity for middle-income countries while reducing it for the high income. In addition, it captures the initial decline of energy demand in response to income growth in most LICs which is, probably, the result of graduation from biomass - an inefficient source of energy. ${ }^{22}$

The maximum income elasticity is precisely estimated and statistically slightly higher than 1 (Table 3). Under the baseline specification it is reached at about \$10,000 (2011 USD) income per capita - below the 2015 global per capita income of $\$ 15000$ and already reached by various emerging markets. Passed this income level the elasticity starts to decline, but slowly. The economy reaches energy saturation at about $\$ 107,000$ (2011 USD). The point is far in the future for any country and imprecisely estimated. ${ }^{23}$ The distribution of the static

\footnotetext{
${ }^{22}$ Biomass (solid biofuels excluding charcoal) is, in fact, an inferior good implying that households reduce its use as income grows. The US "graduated" from biomass in the last quarter of the $19^{\text {th }}$ century when wood was replaced by coal as primary energy source (EIA 2018). The share of biomass in total primary energy supply of the country tends to decline as income grows (Bogmans et al 2018).

${ }^{23}$ An economy with a $\$ 50,000$ per capita income today (e.g., Germany) growing at 2 percent per year would take almost 39 years to reach $\$ 107,000$.
} 
saturation point is also strongly skewed to the right, as shown by Monte Carlo simulations which suggest a 95 percent confidence interval between $\$ 81,000$ to $\$ 162,000$ (Figure 6 and Table 3). ${ }^{24}$ This result is not completely surprising since we are controlling for energy saving, but it poses an estimation problem because estimates mostly rely on out-of-sample projections of the Kuznets curve as no country has reached such income level.

The dynamic saturation point is less subject to this problem as $z<y_{s}$ (see Section III). Assuming income growth as laid out in the previous section, the median estimate of the dynamic saturation point is about $\$ 42,850$, lower than the static saturation's one, already passed by 15 economies including the US, Germany, Japan and Singapore, and more precisely estimated (see Table 3 and Figure 6). ${ }^{25}$

Figure 6

Distribution of Saturation Points Estimates; spec 4
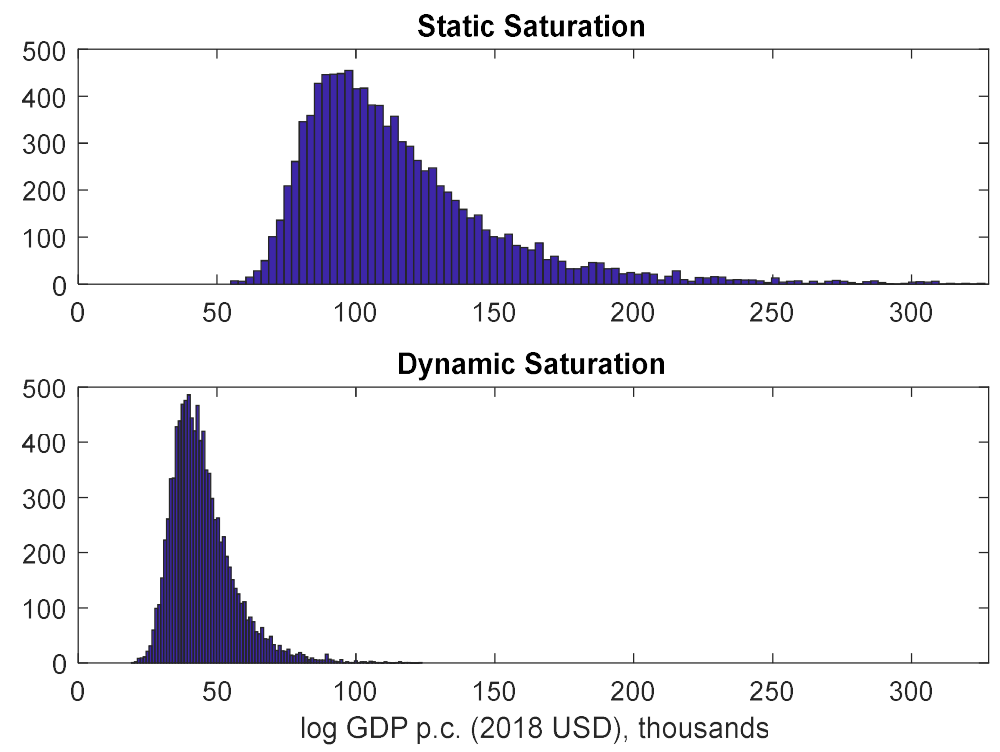

Source: Energy Demand dataset, see Historical Data Appendix. Note: The top (bottom) panel shows the distribution of 10,000 Monte Carlo draws of the static (dynamic) saturation point, from specification 4 (Table 2). The dash red line is the point estimate Kuznet curve. Dot dashed line is the unitary elasticity.

\footnotetext{
${ }^{24}$ Saturation estimates are also naturally skewed to the right because as $\beta_{3} \rightarrow 0$ and $\beta_{2} \rightarrow 0$ (i.e., the linear model) saturation points tend to go to infinity.

${ }^{25} \mathrm{We}$ assume zero population growth in calculating the dynamic saturation point since population tends to grow slowly at high income levels.
} 
Table 3: Median Estimates and Confidence Intervals

\begin{tabular}{|c|c|c|c|c|c|c|c|c|}
\hline & $(1)$ & $(2)$ & $(3)$ & $(4)$ & (5) & (6) & $(7)$ & $(8)$ \\
\hline Dynamic Saturation Point & - & - & $\begin{array}{c}42,714 \\
{[33,440,57,950]}\end{array}$ & $\begin{array}{c}42,845 \\
{[32,970,59,730]}\end{array}$ & $\begin{array}{c}72,281 \\
{[44,890,158,440]}\end{array}$ & $\begin{array}{c}90,146 \\
{[52,910,213,080]}\end{array}$ & $\begin{array}{c}29,550 \\
{[25,340,34,100]}\end{array}$ & $\begin{array}{c}53,117 \\
{[36,930,77,870]}\end{array}$ \\
\hline Static Saturation Point & - & - & $\begin{array}{c}106,530 \\
{[78,460,166,840]}\end{array}$ & $\begin{array}{c}107,380 \\
{[81,170,162,250]}\end{array}$ & $\begin{array}{c}211,900 \\
{[126,270,530,640]}\end{array}$ & $\begin{array}{c}211,900 \\
{[126,270,530,640]}\end{array}$ & $\begin{array}{c}41,329 \\
{[34,860,49,900]}\end{array}$ & $\begin{array}{c}65,502 \\
{[42,760,122,090]}\end{array}$ \\
\hline Graduation from Biomass & - & - & $\begin{array}{c}904 \\
{[703,1,090]}\end{array}$ & $\begin{array}{c}904 \\
{[672,1,112]}\end{array}$ & $\begin{array}{c}952 \\
{[684,1,191]}\end{array}$ & $\begin{array}{c}952 \\
{[684,1,191]}\end{array}$ & $\begin{array}{c}1,069 \\
{[939,1,186]}\end{array}$ & $\begin{array}{c}996 \\
{[746,1,218]}\end{array}$ \\
\hline Max Elasticity & $\begin{array}{c}0.8994 \\
{[0.8658,0.9330]}\end{array}$ & $\begin{array}{c}0.9299 \\
{[0.8773,0.9836]}\end{array}$ & $\begin{array}{c}1.0531 \\
{[1.0089,1.0979]}\end{array}$ & $\begin{array}{c}1.0521 \\
{[1.0013,1.1022]}\end{array}$ & $\begin{array}{c}1.0519 \\
{[0.9978,1.1099]}\end{array}$ & $\begin{array}{c}1.0519 \\
{[0.9978,1.1099]}\end{array}$ & $\begin{array}{c}0.8265 \\
{[0.7529,0.9065]}\end{array}$ & $\begin{array}{c}0.6311 \\
{[0.5344,0.7340]}\end{array}$ \\
\hline Inflection Point & - & - & $\begin{array}{c}9,817 \\
{[8,247,12,085]}\end{array}$ & $\begin{array}{c}9,854 \\
{[8,457,11,718]}\end{array}$ & $\begin{array}{c}14,221 \\
{[1,101,21,080]}\end{array}$ & $\begin{array}{c}14,221 \\
{[1,101,21,080]}\end{array}$ & $\begin{array}{c}6,645 \\
{[6,042,7,285]}\end{array}$ & $\begin{array}{c}8,063 \\
{[6,400,10,761]}\end{array}$ \\
\hline
\end{tabular}

Note: Based on Monte Carlo simulation of 100,000 samples. The income elasticities for the quadratic and cubic specifications are calculated at $\$ 15000$ per capita GDP.

[ ] represent 10th and 90th percentile confidence intervals, repsectively. For the description of the specifications see Table 2. 
The contribution of manufacturing to energy demand is substantial. A 1 percentage point (standard deviation) increase in the manufacturing share increases a country's energy demand by 1.6 (6) percent. As noticed, the trend decline in global manufacturing covaries with time dummies. This suggests that some of the energy efficiency gains stem directly from productivity improvements in the manufacturing sector, globally. This average contribution is about 0.2 percentage points per year which is the difference between the estimates of energy efficiency in specification (6) and (5). The role for offshoring and relocating manufacturing production outside advanced economies is substantial. For example, it accounts for as much as 3.1 (4.1) percent reduction in energy demand in the US between 1990 and 2010 (1990-2017) while the relocation of manufacturing to China between 1990-2010 (1990-2017) accounts for a 14 (10.7) percent increase in energy consumption.

The role of manufacturing can also be seen comparing the Kuznets curve under specification (4) and (6). Since higher income levels are associated with lower manufacturing shares, when we control for the manufacturing share not only energy efficiency's estimates are reduced but also the Kuznets curve is shifted to the right increasing both saturation points substantially.

Finally, not surprisingly, energy demand moves in lockstep with population as its coefficient is very close to 1 in most specifications. When it is substantially above one, it casts a doubt on the econometric specification used. The estimated coefficient on land area is significant and implies that when population density halves (i.e., the land area doubles for a given population) energy demand increases by about 10 percent (Table 2). Doubling both population and land area more than double energy demand, suggesting that "big countries" consume relatively more. Other variables (not shown), such as latitude or winter/summer temperature, are often not significant, possibly due to collinearity with income. ${ }^{26}$

The presence of population "inflates" the overall R-squared; however, even when estimated in per capita terms (having replaced land with population density) all results are retained and the R-square is about 0.94 , suggesting that the baseline specification captures a substantial variation of per capita energy demand across time and countries. ${ }^{27}$

\footnotetext{
${ }^{26}$ The area of a country increases energy demand as a large area requires more travelling given population size, income, and other country characteristics. Results of the regressions that include distance from equator and average winter and summer temperatures are available upon request to the authors.

${ }^{27}$ Results of regressions when energy demand is introduced in per capita terms are available upon request.
} 
Estimation Uncertainty
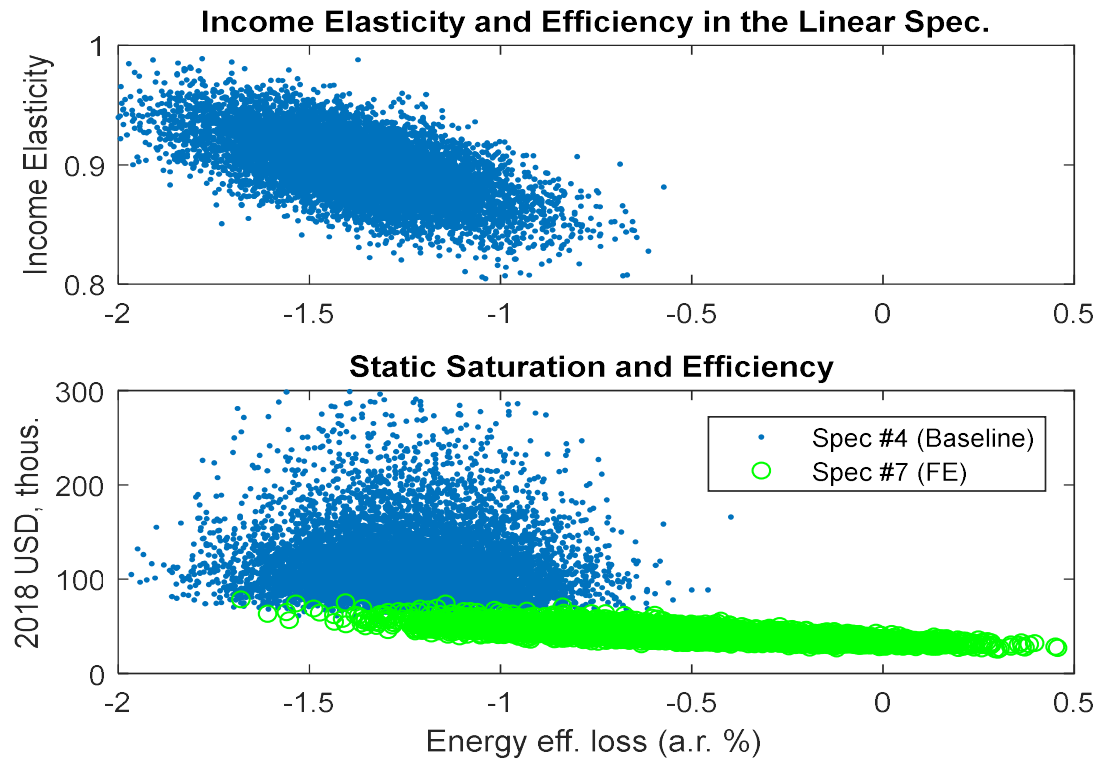

Source: Energy Demand dataset, see Historical Data Appendix.

Note: The top (bottom) panel shows a scatter plot of 10,000 Monte Carlo draws of the average

energy efficiency loss and the income elasticity (static saturation) point, from specification 1 (4), see Table 2.

Country fixed effects flatten dramatically the Kuznets curve reducing the income elasticity and the static saturation point to the extent that energy efficiency gains are no longer needed to explain the observed slowing pace of energy demand in various advanced economies (Figure 3 and Table 2). The covariation of the estimates of the efficiency gain and the saturation point is suspiciously high (the higher the gains the higher the saturation, Figure 7 bottom panel) and the coefficient on population is questionable pointing to an identification problem introduced by the country fixed effects that is absent in the baseline specification. For example, a coefficient on population higher than 1 implies that the relatively higher per capita energy growth of emerging markets could be explained, erroneously, by their faster population growth - a 1 percentage point higher population growth would imply a 10 percent faster energy growth! The problem introduced by country fixed effects is in part due to the use of weighted least squares which further reduce the role of the cross-section as weights put the emphasis on a few big energy consumers. Indeed, in Specification 8, using OLS, results are more in line with the baseline specification. In the next section, we will analyze robustness and repeat the regressions on our novel historical dataset.

\section{Historical Regressions AND Robustness}

\section{A. Historical Regressions}

Group 1 consists of 10 advanced economies (e.g., Belgium, Germany, US, ...) that experienced a relatively similar development path and similar business cycles. The sample starts in 1850. The use of time dummies is, thus, problematic because it explains most of the energy variations. We have, thus, replaced time dummies with a time trend. Signs point to a 
Kuznets curve, but coefficients are significant only when country fixed effects are introduced. Group 2 has already enough cross-sectional variation to re-introduce time dummies, while the sample starts in 1900 and includes Japan, Italy, the USSR, and Brazil. Similarly, the sample of Group 3 starts in 1950 and includes China, Poland, Turkey and South Africa. In contrast to Group 1 and like our main panel, the coefficients on the polynomial are significant for Group 2 and 3 even without fixed effects.

Overall, the Kuznets curve is well-preserved in the Group 2 and Group 3 historical panels, and results point to strong efficiency gains over the sample starting after WWI (Figure 8). The post-WWII boom period of 1950-1970, which saw the rapid expansion of electricity generation and automobile transportation and the concomitant rise of oil consumption in advanced economies, appears to be an exception, as energy efficiency looks rather constant during this era of rapid growth (Figure 8). ${ }^{28}$

Figure 8

\section{Historical Energy Efficiency Gains}


Source: Energy Demand dataset, see Historical Data Appendix.

Note: The blue line represents the time dummies estimated in regression (4), Table 2 . The dotted line is the time trend of specification 3 , group 1; the light gray and dashed lines are time dummies of specification 8 and 13, see Table Historical Regressions. Series have been rebased to year 1971.

${ }^{28}$ Likewise, Griffin and Schulman (2005), using a panel dataset of energy consumption per capita for 16 OECD countries between 1961 and 1991, observe that up to 1973 and the onset of Arab oil embargo there is no discernible negative trend in their time dummies. 
Table 4: Historical Regressions

\begin{tabular}{|c|c|c|c|c|c|c|c|c|c|c|c|c|c|c|c|}
\hline & \multicolumn{5}{|c|}{ Group 1} & \multicolumn{5}{|c|}{ Group 2 } & \multicolumn{5}{|c|}{ Group 3} \\
\hline & (1) & (2) & (3) & (4) & (5) & (6) & (7) & (8) & (9) & (10) & (11) & (12) & (13) & (14) & (15) \\
\hline Population & $\begin{array}{l}1.042^{\star * \star} \\
(0.0467)\end{array}$ & $\begin{array}{l}1.016^{\star \star *} \\
(0.0877)\end{array}$ & $\begin{array}{l}1.051^{* \star *} \\
(0.0512)\end{array}$ & $\begin{array}{l}1.189^{\star \star *} \\
(0.116)\end{array}$ & $\begin{array}{l}1.165^{\star \star *} \\
(0.132)\end{array}$ & $\mid \begin{array}{l}1.020^{\star \star \star} \\
(0.0414)\end{array}$ & $\begin{array}{l}1.206^{\star \star *} \\
(0.174)\end{array}$ & $\begin{array}{l}1.020^{* * *} \\
(0.0433)\end{array}$ & $\begin{array}{l}1.263^{* \star *} \\
(0.159)\end{array}$ & $\begin{array}{l}1.316^{\star \star *} \\
(0.163)\end{array}$ & $\begin{array}{l}1.013^{* \star \star} \\
(0.0367)\end{array}$ & $\begin{array}{l}1.207^{\star \star \star} \\
(0.209)\end{array}$ & $\begin{array}{l}1.013^{\star \star *} \\
(0.0378)\end{array}$ & $\begin{array}{l}1.176^{\star \star *} \\
(0.174)\end{array}$ & $\begin{array}{l}1.251^{* * *} \\
(0.177)\end{array}$ \\
\hline GDP per capita (p.c.) & \begin{tabular}{|l}
-3.372 \\
$(10.04)$
\end{tabular} & $\begin{array}{l}-19.78^{\star *} \\
(6.053)\end{array}$ & $\begin{array}{l}-2.747 \\
(9.786)\end{array}$ & $\begin{array}{l}-16.10^{*} \\
(5.090)\end{array}$ & $\begin{array}{l}-16.05^{\star *} \\
(4.389)\end{array}$ & $\begin{array}{l}-7.467^{\star} \\
(3.554)\end{array}$ & $\begin{array}{l}-17.61^{* * *} \\
(4.035)\end{array}$ & $\begin{array}{l}-7.803 \\
(3.815)\end{array}$ & $\begin{array}{l}-18.88^{\star \star *} \\
(3.139)\end{array}$ & $\begin{array}{l}-18.72^{\star \star \star} \\
(3.139)\end{array}$ & $\begin{array}{l}-14.75^{* \star *} \\
(3.209)\end{array}$ & $\begin{array}{l}-14.84^{* * *} \\
(2.762)\end{array}$ & $\begin{array}{l}-14.59^{\star * *} \\
(2.852)\end{array}$ & $\begin{array}{l}-15.42^{\star * *} \\
(1.834)\end{array}$ & $\begin{array}{l}-15.55^{\star \star \star} \\
(1.828)\end{array}$ \\
\hline$(G D P \text { p.c. })^{\wedge} 2$ & $\begin{array}{l}0.676 \\
(1.040)\end{array}$ & $\begin{array}{l}2.341^{\star *} \\
(0.628)\end{array}$ & $\begin{array}{l}0.615 \\
(1.010)\end{array}$ & $\begin{array}{l}2.005^{\star *} \\
(0.546)\end{array}$ & $\begin{array}{l}1.969^{* *} \\
(0.455)\end{array}$ & $\begin{array}{l}0.917^{*} \\
(0.392)\end{array}$ & $\begin{array}{l}2.096^{\star \star \star} \\
(0.464)\end{array}$ & $\begin{array}{l}0.953^{*} \\
(0.413)\end{array}$ & $\begin{array}{l}2.182^{\star \star \star} \\
(0.357)\end{array}$ & $\begin{array}{l}2.213^{\star \star \star} \\
(0.357)\end{array}$ & $\begin{array}{l}1.751^{\star \star \star} \\
(0.350)\end{array}$ & $\begin{array}{l}1.801^{\star \star \star} \\
(0.311)\end{array}$ & $\begin{array}{l}1.732^{\star \star \star} \\
(0.309)\end{array}$ & $\begin{array}{l}1.804^{\star \star *} \\
(0.214)\end{array}$ & $\begin{array}{l}1.879^{\star \star \star} \\
(0.210)\end{array}$ \\
\hline$(G D P \text { p.c. })^{\wedge} 3$ & \begin{tabular}{|l}
-0.0302 \\
$(0.0360)$
\end{tabular} & $\begin{array}{l}-0.0880^{\star *} \\
(0.0214)\end{array}$ & $\begin{array}{l}-0.0282 \\
(0.0349)\end{array}$ & $\begin{array}{l}-0.0780^{\star \star} \\
(0.0194)\end{array}$ & $\begin{array}{l}-0.0756^{\star \star \star} \\
(0.0156)\end{array}$ & \begin{tabular}{|l}
$-0.0327^{*}$ \\
$(0.0143)$
\end{tabular} & $\begin{array}{l}-0.0794^{\star \star \star} \\
(0.0176)\end{array}$ & $\begin{array}{l}-0.0340^{\star} \\
(0.0147)\end{array}$ & $\begin{array}{l}-0.0805^{\star \star \star} \\
(0.0134)\end{array}$ & $\begin{array}{l}-0.0834^{\star \star \star} \\
(0.0133)\end{array}$ & $\begin{array}{l}-0.0645^{\star \star \star} \\
(0.0126)\end{array}$ & $\begin{array}{l}-0.0688^{\star \star *} \\
(0.0118)\end{array}$ & $\begin{array}{l}-0.0638^{\star \star \star} \\
(0.0110)\end{array}$ & $\begin{array}{l}-0.0669^{* * \star} \\
(0.00841)\end{array}$ & $\begin{array}{l}-0.0717^{\star \star \star} \\
(0.00814)\end{array}$ \\
\hline Area & $\begin{array}{l}0.0484 \\
(0.0384)\end{array}$ & & $\begin{array}{l}0.0436 \\
(0.0405)\end{array}$ & & & $\begin{array}{l}0.0897^{* *} \\
(0.0293)\end{array}$ & & $\begin{array}{l}0.0891^{* *} \\
(0.0295)\end{array}$ & & & $\begin{array}{l}0.110^{* \star *} \\
(0.0300)\end{array}$ & & $\begin{array}{l}0.110^{* * *} \\
(0.0300)\end{array}$ & & \\
\hline Year & $\mid \begin{array}{l}-0.0159^{* *} \\
(0.00478)\end{array}$ & $\begin{array}{l}-0.00508^{*} \\
(0.00222)\end{array}$ & $\begin{array}{l}-0.0158^{*} \\
(0.00495)\end{array}$ & $\begin{array}{l}-0.00692^{*} \\
(0.00266)\end{array}$ & $\begin{array}{c}-0.00668^{*} \\
(0.00246)\end{array}$ & & & & & & & & & & \\
\hline Manufacturing Share & & & & $\begin{array}{l}-0.00501 \\
(0.00375)\end{array}$ & & & & & $\begin{array}{l}0.0203^{\star \star \star} \\
(0.00476)\end{array}$ & & & & & $\begin{array}{l}0.0205^{\star \star *} \\
(0.00308)\end{array}$ & \\
\hline Manufacturing Share (ort.) & & & $\begin{array}{l}0.00226 \\
(0.00598)\end{array}$ & & $\begin{array}{l}0.00243 \\
(0.00376)\end{array}$ & & & $\begin{array}{l}0.0195^{\star} \\
(0.00832)\end{array}$ & & $\begin{array}{l}0.0203^{\star \star \star} \\
(0.00476)\end{array}$ & & & $\begin{array}{l}0.0209^{\star \star *} \\
(0.00384)\end{array}$ & & $\begin{array}{l}0.0205^{\star \star \star} \\
(0.00308)\end{array}$ \\
\hline Energy Efficiency (a.r. 1971-2017, \%) & $-1.59^{\star \star}$ & $-0.51^{*}$ & $-1.58^{\star \star}$ & $-0.69^{*}$ & $-0.67^{\star}$ & $-1.87^{\star \star \star}$ & -0.71 & $-1.86^{\star \star \star}$ & -0.54 & -0.83 & $-1.35^{\star \star \star}$ & -0.75 & $-1.35^{\star \star \star}$ & -0.39 & -0.75 \\
\hline Energy Efficiency (a.r. year0-2017, \%) & $-1.59^{\star \star}$ & $-0.51^{*}$ & $-1.58^{* *}$ & $-0.69^{*}$ & $-0.67^{\star}$ & $-1.27^{\star \star \star}$ & -0.49 & $-1.27^{* \star *}$ & -0.59 & -0.63 & $-1.01^{* \star *}$ & -0.44 & $-1.12^{\star \star \star}$ & -0.18 & -0.52 \\
\hline Constant & $\begin{array}{l}21.26 \\
(29.67)\end{array}$ & $\begin{array}{l}56.50^{*} \\
(21.10)\end{array}$ & $\begin{array}{l}18.98 \\
(27.63)\end{array}$ & $\begin{array}{l}45.01^{*} \\
(16.98)\end{array}$ & $\begin{array}{l}45.44^{*} \\
(14.53)\end{array}$ & $\begin{array}{l}9.573 \\
(10.58)\end{array}$ & $\begin{array}{l}38.66^{\star *} \\
(11.27)\end{array}$ & $\begin{array}{l}10.63 \\
(11.61)\end{array}$ & $\begin{array}{l}42.77^{\star \star *} \\
(8.838)\end{array}$ & $\begin{array}{l}40.85^{\star * *} \\
(8.878)\end{array}$ & $\begin{array}{l}30.00^{* *} \\
(9.871)\end{array}$ & $\begin{array}{l}29.56^{* *} \\
(9.024)\end{array}$ & $\begin{array}{l}29.65^{\star \star} \\
(8.828)\end{array}$ & $\begin{array}{l}32.92^{\star \star *} \\
(6.207)\end{array}$ & $\begin{array}{l}31.27^{* * *} \\
(6.289)\end{array}$ \\
\hline Observations & 1467 & 1467 & 1364 & 1364 & 1364 & 2600 & 2600 & 2245 & 2245 & 2245 & 3826 & 3872 & 3240 & 3275 & 3275 \\
\hline \# of countries & 10 & 10 & 10 & 10 & 10 & 27 & 27 & 27 & 27 & 27 & 58 & 59 & 57 & 58 & 58 \\
\hline Static Saturation Point & 130716 & 48251 & 131321 & 44415 & 49050 & 325101 & 43052 & 308484 & 55352 & 43554 & 90817 & 47481 & 92277 & 60453 & 45910 \\
\hline Dynamic Saturation Point & 68140 & 28107 & 67703 & 26266 & 28288 & 68964 & 31511 & 66935 & 37470 & 28561 & 40835 & 35847 & 36208 & 56938 & 32345 \\
\hline $\begin{array}{l}\text { R-sq } \\
\text { model }\end{array}$ & $\begin{array}{l}0.99 \\
\text { wls }\end{array}$ & $\begin{array}{l}1.00 \\
\text { wls - fe }\end{array}$ & $\begin{array}{l}0.99 \\
\text { wls }\end{array}$ & $\begin{array}{l}1.00 \\
\text { wls - fe }\end{array}$ & $\begin{array}{l}1.00 \\
\text { wls - fe }\end{array}$ & $\begin{array}{l}0.98 \\
\text { wls }\end{array}$ & $\begin{array}{l}0.99 \\
\text { wls - fe }\end{array}$ & $\begin{array}{l}0.98 \\
\text { wls }\end{array}$ & $\begin{array}{l}1.00 \\
\text { wls - fe }\end{array}$ & $\begin{array}{l}1.00 \\
\text { wls - fe }\end{array}$ & $\begin{array}{l}0.98 \\
\text { wls }\end{array}$ & $\begin{array}{l}1.00 \\
\text { wls - fe }\end{array}$ & $\begin{array}{l}0.98 \\
\text { wls }\end{array}$ & $\begin{array}{l}1.00 \\
\text { wls - fe }\end{array}$ & $\begin{array}{l}1.00 \\
\text { wls - fe }\end{array}$ \\
\hline
\end{tabular}

Sources: Buera and Kabobski; Maddison; Mitchell; World Bank; United Nations; and IMF staff calculations

Note: The sample is a balanced panel for 1850-2017 (Group 1), 1900-2017 (Group 2) and 1950-2017 (Group 3). Robust standard errors clustered at the country level in parentheses. All variables in logarithmic scale expect "manufacturing share" and "year". Average elasticity is calculated at 15,000 2011 international USD. All regressions incorporate year fixed effects, except Group 1; fe = country fixed effects; ols $=$ ordinary least squares; wls = weighted least squares. Manufacturing Share (ort.) has been orthogonalized to a third order income p.c. Please see appendix for country list.

${ }^{*} p<0.05,{ }^{* *} p<0.01,{ }^{* * *} p<0.001$ 
For each historical panel, the dynamic saturation point is calculated based on the trend in the efficiency gains over the entire historical sample. The point estimates of dynamic saturation from the historical panels are typically larger, at around $\$ 68,000(67,000)$ for the panel 1850 2017 (1900-2017), but since these panels contain fewer countries than our main panel, it is not straightforward to determine whether the Kuznets curve and its characteristics such as the dynamic saturation point have changed over time, and in what direction. Results point to larger efficiency gains in the order of 1.6 (1.3) percent per year for the panel 1850-2017 (1900-2017) compared to 1.2 percent for the period 1971-2017, perhaps indicating that (some of) the low-hanging energy efficiency fruits have already been harvested by past innovators (Gordon 2012, Bloom et al. 2020).

\section{B. Robustness}

In this section we perform a series of robustness tests.

Testing for outliers. We drop one country at the time to see identify potential outliers (Figure 9). Dropping the US (China) from the regression reduces (increases) the energy efficiency gains by about $0.4(0.2)$ percentage point while the peak of the Kuznets curves decreases (increases) by $\$ 25,000(\$ 60,000)$. Since efficiency gains and static saturation move in opposite direction dynamic saturation is less affected. It is, thus, important to include both countries - especially when using weighted least squares. This is in part due to the opposing evolution of the manufacturing sector in the two countries. Indeed, the rise of China as manufacturing powerhouse increased her energy demand by [14] percent (see Section Results). Interestingly, omitting Ethiopia from the sample increases the saturation point, probably, because Ethiopia helps capture graduation from biomass.

Figure 9

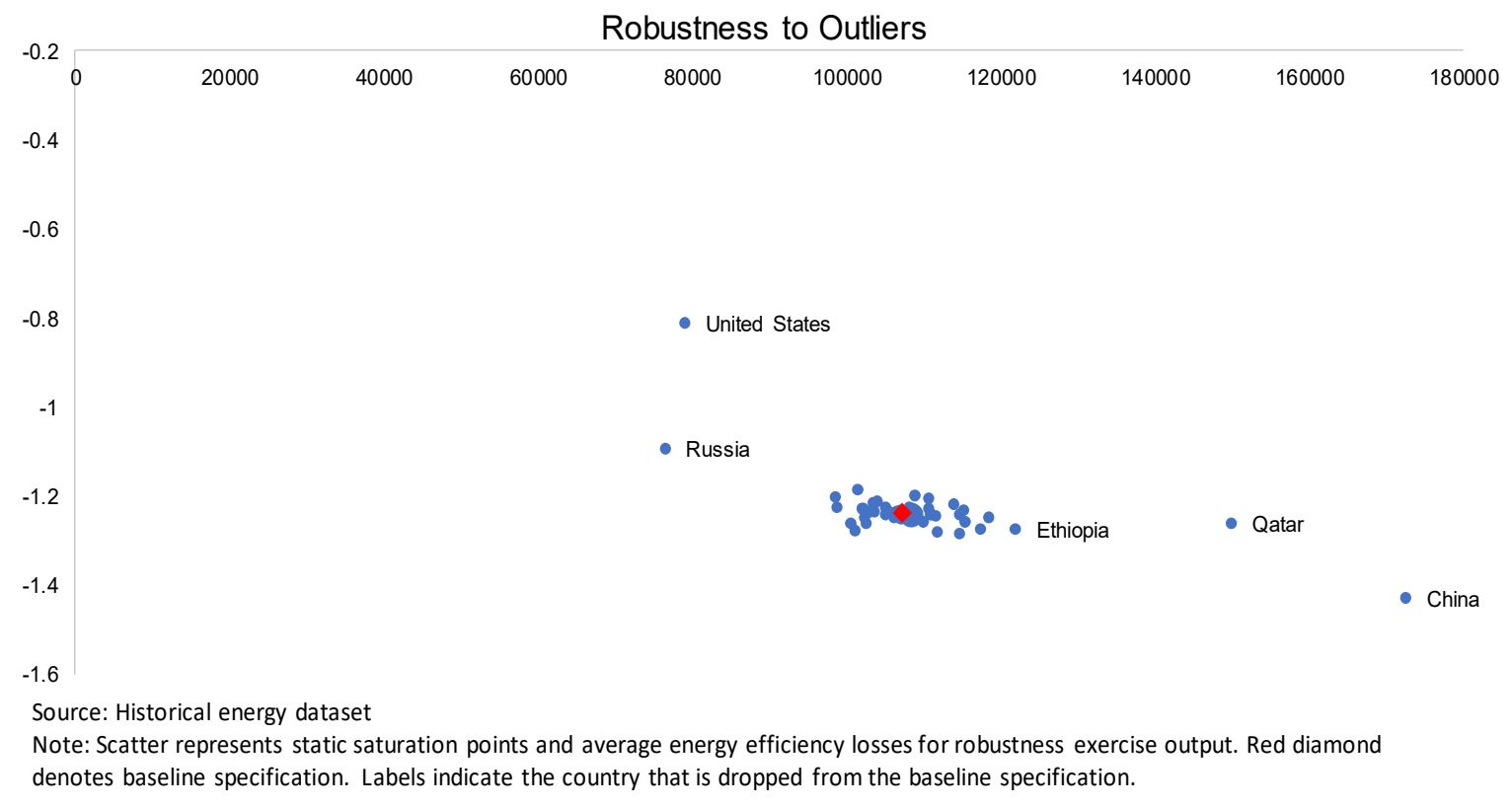


Energy Exporters and Transition Economies. We now introduce energy exporters and transition economies one at a time to see their impact on the estimation. ${ }^{29} \mathrm{We}$ would expect energy exporters to increase the saturation point as energy sources are locally abundant (i.e. cheap) and, usually have better energy infrastructure. Also, oil and gas discoveries may positively correlate with income per capita moving both energy consumption and GDP together even at high income levels. These effects are exemplified by adding Qatar.

Transition economies pose a different problem, mostly affecting time dummies in the early 90 s as energy-inefficient countries entered the sample. Also, most of them experienced a collapse of (inefficient) domestic manufacturing sectors during the transition which then led them to a fast recovery of energy efficiency. The most notable example is Russia, whose introduction reduces both the average rate of energy efficiency gains and the static saturation point.

Additional variables. Results are qualitatively robust to different specifications, including "distance from the equator" and "average winter and summer temperature" (not shown), which serve as proxies for intrinsic demand for cooling and heating energy services, reducing the significance of income. This is not surprising, however, as Hall and Jones (1999) and other scholars have used distance from the equator to instrument output per worker.

A dynamic panel. Finally, a dynamic panel (where energy is introduced as lagged dependent variable) and a specification where energy is in per capita terms deliver qualitatively similar results. The use of the dynamic panel, however, has not been chosen as baseline because the interpretation of the coefficients is more problematic, introducing a short- and long-term Kuznets curve.

Per capita specification and cross-sectional dependence. A specification where energy demand is already expressed in per capita terms is useful to have a better idea of the goodness of fit of the regression. When we specify the baseline specification of Section Results using per capita energy (dropping population and replacing land area with density) we find qualitatively similar results, but R-squared is somewhat lower than in Table 2's regressions but still as high as 0.94 . When we specify specification 8 (OLS FE) of Section Results using per capita energy we find an overall R-squared of 0.79 while the within and between R-squared equal respectively 0.56 and 0.84 .

Finally, even though we cannot rule out cross-sectional dependence, its effects on estimates are probably modest given the use of year dummies. To inspect robustness to cross-sectional dependence, we ran 47 cross-section regressions, one for each year of our main panel. Results show point estimates that corroborate the Kuznets curve previously found and are statically significant from 2006 onwards (and the signs of the three polynomial coefficients often point in the right direction in the years before that), highlighting the importance of using recent data. Extending this cross-sectional angle, we also repeated regression Table 2 by employing the between estimator, which discards the time variation in the data. The Kuznets curve remains highly significant. Focusing alternatively on the time-dimension, we

\footnotetext{
${ }^{29}$ The use of a time-varying energy-exporter and coal producer dummy, has proved too crude to fully capture the relation between fossil fuel wealth and income. Also, coal abundance is usually associated with higher energy consumption even for countries that are energy importers (such as China and India). In general, the introduction of energy exporters weakens the link between energy and income.
} 
used our longest historical panel to regress, by country, energy demand per capita on population, the income polynomial, four lags of real oil prices and a year trend. For 10 out of 11 countries of Group 1, we find significant evidence of a Kuznets curve, and for 7 out of 11 countries the year trend is negative and statistically significant, indicating energy efficiency gains. ${ }^{30}$

\section{Conclusions}

A Kuznets curve seems to characterize the relationship between energy demand and economic development (proxied by per capita income). Moreover, once controlling for manufacturing and the effect of common factors, our preferred specification can explain a large part of energy demand variation over time and across countries. The main benefit of estimating a Kuznets curve is allowing a non-constant income elasticity of energy demand that can capture what seems a typical pattern in the data: an initial decline of energy demand at low levels of income that is followed by stages of acceleration and then saturation at highincome levels. This cannot be captured by neither linear nor quadratic specifications.

The highest value for the elasticity of energy to income is slightly above 1 and is reached at middle-income levels. Based on this elasticity alone, which is very precisely estimated, it seems emerging markets will have to forego growth to slow down their energy consumption. Fortunately, energy efficiency gains have historically played a crucial role in reducing energy demand. These efficiency gains have reduced energy demand by about 1.2 percent per year on average in the past fifty years. In the longer sample, however, energy efficiency gains started to become significant only after WWI when the second industrial revolution was near its end and coal started to give way to more efficient fossil fuels.

In the post WWII period, estimated energy efficiency gains are in part due to fast productivity growth in the manufacturing sector. In fact, the decline of the global manufacturing share (mostly induced by strong productivity growth in manufacturing output till the early 2000s) explains roughly 0.2 percentage points of the annual rate of global energy efficiency gains. At the country level, the role of offshoring and the relocation of manufacturing production has been substantial in some cases. For example, changes in the manufacturing share of GDP between 1990 and 2017 can account for as much as a 4.1 percent decline in US energy consumption and for a 10.7 percent increase of China's energy consumption. Looking forward, it seems that questionable that we will see a re-shuffling of the manufacturing sector across countries to the extent we have seen in the past, and thus this impact on energy demand will diminish.

The peak of the Kuznets curve (i.e., static saturation) is far into the future, even for AEs, so absolute energy-income decoupling is still far away, being above $\$ 107,000$ per capita income. Energy efficiency gains, however, allows the introduction of a dynamic concept of peak energy demand which is better estimated and more robust to misspecification-because estimates of efficiency gains and static saturation usually move in opposite directions. So rather than relying on a zero-income elasticity, dynamic saturation depends on a combination of factors that allow for a relative decoupling - i.e., a declining but still positive income elasticity and continuous energy efficiency gains that bring about energy saturation at high

${ }^{30}$ These results are available upon request from the authors. 
levels of income. The income necessary to reach dynamic saturation is about $\$ 43,000$, which is already reached by 15 countries in North America, Europe, and the Asia-Pacific region. An important implication of dynamic saturation is that further declines in energy consumption are by no means guaranteed and will depend on future energy efficiency gains to continue to outpace the effect of income growth on energy consumption.

Finally, we find that high oil prices (a proxy for energy prices) have probably affected innovation in energy efficiency but slowly. It is, thus, likely that the decade of high oil and energy prices which ended in 2014 helped stimulate energy efficiency gains in the recent years. Prospects of cheap energy, however, will probably reduce the incentive to innovation in the energy and end-use energy services sectors, in absence of policy interventions. 


\section{REFERENCES}

Acemoglu, Daron, et al. "Import competition and the great US employment sag of the 2000s." Journal of Labor Economics 34.S1 (2016): S141-S198.

Acemoglu, D., Aghion, P., Bursztyn, L., \& Hemous, D. (2012). The environment and directed technical change. American Economic Review, 102(1), 131-66.

Baily, Martin Neil, and Barry P. Bosworth. "US manufacturing: Understanding its past and its potential future." Journal of Economic Perspectives 28.1 (2014): 3-26.

Barro, Robert. J., Sala-i-Martin, Xavier, I. (2004). Economic growth. $2^{\text {nd }}$ edition. MIT press.

Bloom, N., Jones, C. I., Van Reenen, J., \& Webb, M. (2020). Are ideas getting harder to find?. American Economic Review, 110(4), 1104-44.

Bogmans, Christian, Kiyasseh, Lama, Matsumoto, Akito, Pescatori, Andrea, and Julia Xueliang Wang (2018), Special Feature: Commodity Market Developments and Forecasts with a Focus on Recent Trends in Energy Demand, in: International Monetary Fund. 2018. World Economic Outlook: Challenges to Steady Growth. Washington, DC, October.

Bolt, Jutta, Robert Inklaar, Herman de Jong, and Jan Luiten Van Zanden. "Rebasing 'Maddison': new income comparisons and the shape of long-run economic development." GGDC Research Memorandum 174 (2018).

Bonus, Holger. "Quasi-Engel Curves, Diffusion, and the Ownership of Major Consumer Durables." Journal of Political Economy 81, no. 3 (1973): 655-77.

Buera, Francisco J., and Joseph P. Kaboski. "Scale and the origins of structural change." J. Economic Theory 147, no. 2 (2012): 684-712.

Burke, Paul J., and Zsuzsanna Csereklyei. "Understanding the energy-GDP elasticity: A sectoral approach." Energy Economics 58 (2016): 199-210.

Cohen, Gail, João Tovar Jalles, Mr Prakash Loungani, and Ricardo Marto. Emissions and growth: Trends and cycles in a globalized world. International Monetary Fund, 2017.

Csereklyei, Zsuzsanna, M. D. Mar Rubio-Varas, and David I. Stern. "Energy and economic growth: the stylized facts." The Energy Journal 37, no. 2 (2016).

Dargay, Joyce, and Dermot Gately. "Income's effect on car and vehicle ownership, worldwide: 1960-2015." Transportation Research Part A: Policy and Practice 33, no. 2 (1999): 101-138.

Dargay, Joyce, Dermot Gately, and Martin Sommer. "Vehicle ownership and income growth, worldwide: 1960-2030." The Energy Journal 28, no. 4 (2007). 
Dudley, Bob. "BP statistical review of world energy." BP Statistical Review, London, UK, accessed Aug 6 (2018): 2018.

EIA, US. "International energy statistics." Washington DC: US Energy Information Administration.(https://www.eia.gov/beta/international/data/browser/ (2018).

Etemad, Bouda, Jean Luciani, Paul Bairoch, and Jean-Claude Toutain. World energy production, 1800-1985. Droz, 1991.

Farrell, Michael J. "The demand for motor-cars in the United States." Journal of the Royal Statistical Society. Series A (General) 117, no. 2 (1954): 171-201.

Fernald, John. 2014. "A Quarterly, Utilization-Adjusted Series on Total Factor Productivity" Federal Reserve Bank of San Francisco Working Paper 2012-19. https://doi.org/10.24148/wp2012-19

Fernandes, S. D., Trautmann, N. M., Streets, D. G., Roden, C. A., \& Bond, T. C., “Global biofuel use, 1850-2000”. Global Biogeochemical Cycles, 2007, 21(2).

Fort, Teresa C., Justin R. Pierce, and Peter K. Schott. 2018. "New Perspectives on the Decline of US Manufacturing Employment." Journal of Economic Perspectives, 32 (2): 47-72.

Fell, Michael James. "Energy services: A conceptual review." Energy research \& social science 27 (2017): 129-140.

Gertler, Paul J., Orie Shelef, Catherine D. Wolfram, and Alan Fuchs. "The demand for energy-using assets among the world's rising middle classes." American Economic Review 106, no. 6 (2016): 1366-1401.

Gordon, R. J. (2012). Is US economic growth over? Faltering innovation confronts the six headwinds (No. w18315). National Bureau of Economic Research.

Greening, Lorna A., David L. Greene, and Carmen Difiglio. "Energy efficiency and consumption — the rebound effect—a survey." Energy policy 28, no. 6-7 (2000): 389401.

Griffin, James M., and Craig T. Schulman. "Price asymmetry in energy demand models: a proxy for energy-saving technical change?" The Energy Journal 26.2 (2005).

Gross, Nachum T. "Economic growth and the consumption of coal in Austria and Hungary 1831-1913." The Journal of Economic History 31, no. 4 (1971): 898-916.

Grossman, Gene M., and Alan B. Krueger. "Economic growth and the environment." The Quarterly Journal of Economics 110, no. 2 (1995): 353-377. 
Hall, Robert E., and Charles I. Jones. "Why do some countries produce so much more output per worker than others?" The Quarterly Journal of Economics 114, no. 1 (1999): 83116.

Harbaugh, W., A. Levinson and D. Wilson (2002), 'Re-examining the Empirical Evidence for an Environmental Kuznets Curve', Review of Economics and Statistics 84(3), 541551.

Holtz-Eakin, Douglas, and Thomas M. Selden. "Stoking the fires? CO2 emissions and economic growth." Journal of Public Economics 57.1 (1995): 85-101.

Huntington, Hillard G., James J. Barrios, and Vipin Arora. "Review of key international demand elasticities for major industrializing economies." Energy Policy 133 (2019): 110878.

IEA, IEA. "Coal Information 2018, IEA.” OECD Publishing. https://www.iea.org/reports/coal-2018. (accessed on 10 July 2018) (2018)

IEA, IEA. Unit converter and glossary, IEA, Paris https://www.iea.org/reports/unitconverter-and-glossary (2018)

IEA, IEA. "World energy statistics (Edition 2018)", IEA World Energy Statistics and Balances (database), https://doi-org.libproxy-imf.imf.org/10.1787/d1cac55b-en (accessed on 01 April 2018) (2018)

IEA, IEA. "World conversion factors (Edition 2018)", IEA World Energy Statistics and Balances (database), https://doi-org.libproxy-imf.imf.org/10.1787/67a87193en (accessed on 03 March 2019) (2018)

IEA, IEA. "World - Coal supply (Edition 2018)", IEA Coal Information Statistics (database), https://doi-org.libproxy-imf.imf.org/10.1787/a1577c3fen (accessed on 03 March 2019) (2018)

IMF. "IMF primary commodity prices." (2019).

Jacks, David S. From boom to bust: A typology of real commodity prices in the long run. No. w18874. National Bureau of Economic Research, 2013.

Jacks, David S. "From boom to bust: A typology of real commodity prices in the long run." Cliometrica 13, no. 2 (2019): 201-220.

Jenkins, B. Properties of Biomass, Appendix to Biomass Energy Fundamentals, EPRI Report TR-102017, January, 1993. http://cta.ornl.gov/bedb/appendix_a/Heat_Content_Ranges_for_Various_Biomass_Fuel s.xls 
Liddle, Brantley, and Hillard Huntington. "Revisiting the income elasticity of energy consumption: A heterogeneous, common factor, dynamic OECD \& non-OECD country panel analysis." The Energy Journal 41, no. 3 (2020).

Malanima, Paolo. "Energy Consumption in Italy in the 19th and 20th Centuries." A Statistical Outline (2006).

Medlock III, Kenneth B., and Ronald Soligo. "Economic development and end-use energy demand." The Energy Journal 22, no. 2 (2001).

Mitchell, Brian. International historical statistics Africa, Asia \& Oceania 1750-1988. Springer, 1992.

Mitchell, Brian. International historical statistics Europe 1750-1988. Springer, 1992.

Mitchell, Brian. International Historical Statistics: The Americas 1750-1988. Springer, 1992.

OECD, NEA. "Forty Years of Uranium Resources, Production and Demand in Perspective." Paris. https://www. oecd-nea. org/ndd/pubs/2006/6096-40-yearsuranium. pdf(2006).

Officer, Lawrence H., and Samuel H. Williamson. "The Annual Consumer Price Index for the United States, 1774-Present." Measuring Worth 2018 (2018).

Schurr, Sam H., Bruce Carlton Netschert, Vera F. Eliasberg, Joseph Lerner, and Hans H. Landsberg. Energy in the American economy, 1850-1975: an economic study of its history and prospects. No. HD9545 R45. 1960.

Selden, T.M. and Song, D., 1994. Environmental quality and development: is there a Kuznets curve for air pollution emissions?. Journal of Environmental Economics and management, 27(2), pp.147-162.

Smil, Vaclac. Biomass Energies: Resources, Links, Constraints, Plenum Press, New York. 1983.

Smil, Vaclav. Energy and civilization: a history. MIT Press, 2017.

Smil, Vaclav. Growth: from microorganisms to megacities. MIT Press, 2019.

Sorrell, Steve. "Jevons' Paradox revisited: The evidence for backfire from improved energy efficiency." Energy Policy 37, no. 4 (2009): 1456-1469.

Stokey, Nancy L. "Are there limits to growth?." International Economic Review (1998): 131. 
Toupet, S. "The Shift Project." Available online: www. tsp-data-portal. org/Breakdown-ofElectricity-Generation-by-Energy-Source\# tspQvChart (accessed on 21 February 2018) (2014).

World, Bank. "World Development Indicators (WDI)." Available online: http://databank.worldbank.org/data/reports.aspx?source=world-developmentindicators (accessed on 15 January 2018) (2018).

UNSD. "Energy statistics database." (2016).

van Benthem, Arthur A. "Energy leapfrogging." Journal of the Association of Environmental and Resource Economists 2, no. 1 (2015): 93-132.

van Benthem, Arthur, and Mattia Romani. "Fuelling growth: what drives energy demand in developing countries?." The Energy Journal 30, no. 3 (2009).

Wolfram, Catherine, Orie Shelef, and Paul Gertler. "How will energy demand develop in the developing world?." Journal of Economic Perspectives 26, no. 1 (2012): 119-38. 


\section{APPENDIX}

This appendix contains (A) a list of countries included in each (historical) panel, (B) a historical data appendix describing all data sources as well as various aspects of cleaning and constructing the dataset, and (C) details of an empirical test that examines the response of cyclical energy savings to global GDP and oil price shocks.

\section{A. List of countries}

\begin{tabular}{|c|c|c|c|c|c|}
\hline Characteristics & Group 1 & Group 2 & Group 3 & Group 4 & Group 5 \\
\hline \# of countries & 11 & 20 & 34 & 40 & 22 \\
\hline \# of countries (cum) & 11 & 31 & 65 & 105 & 127 \\
\hline Year (start) & 1850 & 1900 & 1950 & 1971 & 1991 \\
\hline \multirow[t]{41}{*}{ Sub-groups } & & Group 1+ & Group 2 + & Group 3+ & Group 4+ \\
\hline & Austria & Argentina & Albania & Algeria & Angola \\
\hline & Belgium & Australia & Bolivia & Bahrain & Armenia \\
\hline & Denmark & Brazil & Botswana & Bangladesh & Azerbaijan \\
\hline & France & Canada & China & Benin & Belarus \\
\hline & Germany & Chile & Colombia & Cameroon & Bosnia \\
\hline & Netherlands & Finland & Congo, Democratic Republic of the & Congo, Republic of & Croatia \\
\hline & Norway & Greece & Egypt & Costa Rica & Estonia \\
\hline & Spain & Hungary & Ethiopia & Cyprus & Georgia \\
\hline & Sweden & India & Ghana & Czech Republic & Kazakhstan \\
\hline & United Kingdom & Indonesia & Hong Kong SAR & Dominican Republic & Kyrgyzstan \\
\hline & United States & Italy & Iran & Ecuador & Latvia \\
\hline & & Japan & Ireland & El Salvador & Lithuania \\
\hline & & Mexico & Israel & Gabon & Macedonia \\
\hline & & NewZealand & Kenya & Guatemala & Moldova \\
\hline & & Peru & Luxembourg & Haiti & Mongolia \\
\hline & & Portugal & Malaysia & Honduras & Qatar \\
\hline & & Romania & Morocco & Iceland & Serbia \\
\hline & & Switzerland & Mozambique & & Slovakia \\
\hline & & Bulgaria & Nigeria & Ivory Coast & Slovenia \\
\hline & & USSR* & Pakistan & Jamaica & Tajikistan \\
\hline & & & Philippines & Jordan & Turkmenistan \\
\hline & & & Poland & Lebanon & Uzbekistan \\
\hline & & & South Africa & Libya & Russia* \\
\hline & & & SouthKorea & Malta & \\
\hline & & & Tanzania & Mauritius & \\
\hline & & & Thailand & Myanmar & \\
\hline & & & Tunisia & Nepal & \\
\hline & & & Turkey & Nicaragua & \\
\hline & & & Uruguay & Oman & \\
\hline & & & Vietnam & Panama & \\
\hline & & & Zambia & Paraguay & \\
\hline & & & Zimbabwe & Saudi Arabia & \\
\hline & & & Venezuela & Senegal & \\
\hline & & & Taiwan & Singapore & \\
\hline & & & & SriLanka & \\
\hline & & & & Sudan & \\
\hline & & & & Syria & \\
\hline & & & & Togo & \\
\hline & & & & TrinidadTobago & \\
\hline & & & & Yemen & \\
\hline
\end{tabular}

*USSR/ Russia appears in dataset; USSR until 1990, and Russia starting in 1991

Note: Table reprsents countries categorized in groups by the first year for which energy consumption, income and population are simulatenously available for all countries.

The country sample of regressions in Table 1 includes all countries from Group 5 except those identified as (1) MENA-OPEC and (2) transition countries. MENA-OPEC countries are Algeria, Iran, Iraq, Kuwait, Libya, Qatar, Saudi Arabia, United Arab Emirates.

Transition countries are Albania, Armenia, Azerbaijan, Belarus, Bosnia, Bulgaria, Croatia, Czech Republic, Estonia, Georgia,

Hungary, Kazakhstan, Kosovo, Kyrgyz Republic, Latvia, Lithuania, Macedonia, Moldova, Montenegro, Poland, Romania, Russia, Serbia, Slovakia, Slovenia, Tajikistan, Turkmenistan, Ukraine, USSR and Uzbekistan 


\section{B. Historical Data Appendix}

\section{B1. Introduction}

Data on primary energy demand, TPES (see Section III.A), is taken from the IEA (2018c) for the sample 1971-2017, while for our historical panels we also incorporate data from UN (2016) for the period 1950-1970, data from Mitchell (1992a, 1992b,1992c) for 1850-1970, Etemad and Luciani (1991) for 1850-1970, and several other historical sources (see Historical Data Appendix for further details).

To measure income, we use real GDP per capita in 2011 US dollars, which we obtained from the most recent version of the Maddison database, see Bolt et al. (2018). This measure of real GDP is based on prices that are constant across countries but depend on the current year. Our population variable is also taken from the same Maddison dataset. For a few countries, we complement this information with data from Mitchell (1992b) to come to a more complete dataset. For the share of manufacturing, we constructed a new time-series that uses national accounts data from UNSD (2016) for the period 1971-2017, and data from Buera and Kaboski (2012) for the period 1850-1970.

This paper presents a novel cross-country panel dataset on the production, imports, exports and consumption of energy between 1850 and 2018. To this end we collected annual data of all major primary energy sources, including biofuels, coal, oil, natural gas, hydropower and nuclear energy (all in million tonnes of oil (Mtoe) per year). The dataset is unbalanced. It starts with positive observations for a total of 11 countries in the 1850s. The number of countries then increases to 31 by 1900, 65 by 1950, and finally reaches 127 for our end of sample by $2017 .{ }^{31}$

Our contribution is two-fold. First, post-World War II we connect data from the United Nations (UN) Energy Statistics Database from 1950-1970 to data from the World Energy Balances Database from the International Energy Agency (IEA) from 1971-2018. Second, we contribute to the period 1850-1949 by merging data from various sources. The bulk of our observations for that era originate from the historical data compilations of B.R. Mitchell (all fossil fuels post 1800). Other major sources are Etemad and Luciani (1991) (hydropower data between 1900-1970), Fernandes et al. (2007) (biofuels between 1850-1970), and $\mathrm{OECD} / \mathrm{NEA}$ (2006) (for nuclear energy).

The constructed dataset provides for an integrated perspective on the energy needs of the world economy that covers the age of capital (1850-1875), the first era of globalization (1875-1914), the (inter)war period of 1914-1945, the great acceleration of the 1950s and 1960s post World War II, as well as the oil crisis of the 1970s and the commodity price boom of the 2000s.

In what follows, we describe the construction of the dataset and the choices made in calculating total energy consumption by country.

\footnotetext{
${ }^{31}$ When we ended our data collection efforts in 2019, the IEA's energy supply data for 2018 was still provisional for most countries.
} 


\section{B2. Data Sources and Data Cleaning}

\section{Overview of Data Sources}

We constructed our dataset from various sources. For coal, oil and natural gas before 1950, we rely on output, imports and exports from International Historical Statistics (Africa, Asia and Oceania; Europe; The Americas) by B.R. Mitchell. A compendium of world statistical data, Mitchell (1992a, 1992b,1992c) covers annual country-level data from 1800-1988 and is based on a large number of primary sources, including national publications from organizations like the U.K. Ministry of Fuel and Power, and the Annuaire Statistique de la France, in addition to secondary sources, such as League of Nations and United Nations Statistical Yearbooks. Other secondary sources include historical data compilations by independent historians and researchers.

\section{Calculating Energy Consumption}

TPES is calculated as the sum of production and imports minus exports and stock withdrawals/reductions:

$$
X_{\text {supp }}=X_{\text {prod }}+X_{\text {imp }}-X_{\text {exp }}+X_{\text {stock }}
$$

We calculate energy consumption $X_{\text {supp }}$ of the following primary energy sources: biofuels, coal, oil, natural gas, nuclear energy, hydropower, and other renewables. Note that in order to calculate total oil supply we amend the TPES formula by subtracting international marine bunkers and international aviation bunkers. ${ }^{32}$

\section{Treatment of Missing Values}

Occasionally not all four individual data components are available, which implies that an assumption regarding the values of missing components must be made to calculate energy consumption. In dealing with these missing values, the following rules were followed. First, before 1950 data on stock changes is not available. To calculate TPES for all relevant primary energy sources we therefore assume stock changes to be equal to 0 . Since values for stock changes are typically very small compared to values for production, imports and exports by the time they are first observed in the 1950s, this assumption seems defensible. Second, if the first entry of an energy component falls short of 0.5 million metric tons (MMT) of coal (or its energy equivalent of $0.33 \mathrm{MMT}$ of oil), which is approximately the amount of coal mined by a single British or German coal mine around 1900, we set all preceding values equal to 0 , unless we had country-specific historical information to believe those values had been larger at some stage in history. If, on the other hand, the first entry is larger than 0.5 MMT of coal, we assume that the data is indeed missing before that time and abstain from calculating total energy consumption before that date.

\section{Coal}

Mitchell reports the following output categories for all countries: total coal, hard coal, brown coal; and for the US only, reports bituminous (which is further sub-divided into hard coal and brown coal), and anthracite. For some countries, only total coal output is available, and for

${ }^{32}$ Among others this ensures that total oil supply is not overestimated for countries that serve as a global transport hub, such as the Netherlands and Singapore. 
others, it is a combination of these output categories. Import and export data is available in Mitchell with no hard coal or brown coal specifications. This is important to note because it affects the calorific conversion factors used. For hard coal and brown coal, we supplement production, imports and exports (all in thousand metric tons) for the years 1950-1970 from the UN Energy Statistics Database (UN, 2016). We do this to achieve a more complete dataset as data from Mitchell is sometimes unavailable. To further enlarge our dataset, if data is missing for production, imports or exports, we manually verified for all countries and all years whether we could attribute a 0 , another value, or whether it was truly missing; see Treatment of missing values.

To transform coal weight into coal energy flows for the period 1850-1970, we need to account for the energy content of the various types of coal, which varies by country and year. Using the IEA World Conversion Factors database (2018d), we access annual net calorific values (in kilojoule(kj)/kilogram) for all available countries for the period 1960-2017, for each of anthracite, brown coal, hard coal, lignite and sub-bituminous coal. We then derive the average net calorific value (ncv) by type of coal by taking the three-year average for each country in the year when the first data point appears and assign that ncv to all preceding years, by country and by type of coal. Often, this rule results in imputing values for the earlier years in our dataset $(<1960)$, but also when there are gaps in the data for subsequent years. For the conversion factors, we use country-specific formulas by relying on IEA product definitions when operationalizing these formulas ${ }^{33}$ : for hard coal we use Formula 1; for brown coal we use Formula 2; for total coal, we use Formula 3. In these formulas, we use coal output data from the IEA World - Coal Supply database (2018e).

\section{Formula 1: Hard Coal Calorific Conversion Factor}

(Hard* Coal Calorific Value x Hard* Coal Production) + (Sub-bituminous Coal Calorific Value x Sub-bituminous Coal Production)/ (Hard* Coal Output + Subbituminous Coal Output)

${ }^{*}$ where hard coal is not available, we use anthracite coal instead

Formula 2: Brown Coal Calorific Conversion Factor

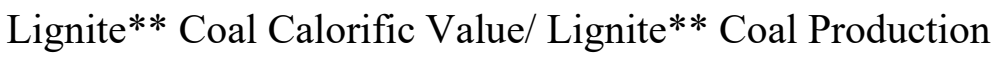

${ }^{*}$ where lignite coal is not available, we use brown coal instead

Formula 3: Total Coal Calorific Conversion Factor

(Hard* Coal Calorific Value x Hard* Coal Production) + (Sub-bituminous Coal Calorific Value x Sub-bituminous Coal Production) + (Lignite** Coal Calorific Value + Lignite** Coal Production)/ (Hard* Coal Output + Sub-bituminous Coal Output + Lignite**)

\footnotetext{
${ }^{33}$ According to the World Energy Balances: Database Documentation (2019 edition), hard coal includes anthracite (among others) and brown coal includes lignite and sub-bituminous coal.
} 
*where hard coal is not available, we use anthracite coal instead

** where lignite coal is not available, we use brown coal instead

For remaining countries, where information on country-specific coal conversion factors is unavailable, we assign the average global calorific conversion factor which represents the average calorific value of all coal consumed globally in a given year. We then multiply our physical volumes by these figures to derive energy content in terajoule (TJ). To convert these variables from TJ to Mtoe, we use a conversion ratio of 23,884.5897 from the IEA unit conversion tool (2018b).

\section{Oil}

Mitchell reports crude output, imports and exports. The unit of measurement (i.e., thousand tons, million metric tons, million gallons or million US gallons) varies by country and time period. We thus first convert all oil output data into thousand tons. For some countries, Mitchell segments the import and export data into several categories e.g. crude petroleum, petroleum products, crude oil, and refined oil, which we aggregate into total imports and total exports by country. For the period 1950-1970 we supplement each of the output, import and export categories with UN data to achieve a more complete dataset. We checked all data manually until 1970 to verify missing data; please see Treatment of missing values. For post 1970, we use IEA.

\section{Natural Gas}

Mitchell reports output data for natural gas but not imports or exports. For the period 19501970 we use data on production, imports and exports (all in TJ) from the UNSD Energy Statistics database (2018) to supplement the Mitchell dataset. For the period 1971-2018 we rely entirely on data from the IEA.

\section{Imports and Exports of Fossil Fuels}

We created import and export series for coal, crude and natural gas, using Mitchell (18501970) and UN data (1950-1970) until 1970, and appended import and export data from the IEA (1971-2017). For natural gas, imports and exports are unavailable before 1950, so pre1950 we set natural gas consumption equal to natural gas production. By the time imports and exports for natural gas first appear in the 1950s their values are very small compared to production value (as trade of natural gas was minimal in earlier years). To append IEA natural gas imports and exports, we multiply the data in TJ by 41.868 to convert it to ktoe, using the IEA (2018b).

\section{Hydropower}

For hydropower, we use data on annual hydroelectricity production (Mtoe), which is available from 1900 to 2014 from The Shift Project (TSP) (2018). TSP (2018) incorporates data from Etemad and Luciani (1991), which represents a compilation of data from official sources as well as the U.S. EIA Historical Statistics. For 1971-2018, we use data from the IEA. 


\section{Nuclear}

For nuclear energy, we use nuclear production data (TWh) from TSP (2018). The first observation is in 1956, the year in which the United Kingdom established the world's first civil nuclear energy program by opening a nuclear power plant in Windscale. The original data source is the OECD Nuclear Energy Agency (See OECD/NEA 2006). ${ }^{34}$ For 1971 and onwards we use data from the IEA.

\section{Biofuels}

For biofuels we create an aggregate consumption measure (in Mtoe), based on domestic and industrial biofuel consumption data that comprises fuelwood, agricultural residues, dung, and charcoal from Fernandes et al. (2007), which is available for 100 countries, and covers the period 1850-2000. This biofuel data is in Gigagram per year $(\mathrm{Gg} / \mathrm{yr})$ and is converted to Mtoe using energy densities derived from various sources, including Smil (1983) and Jenkins (1993). ${ }^{35}$

\section{Renewable Energy}

We calculate renewable energy as the sum of hydropower and biofuels consumption up to 1970 and use the IEA TPES data on renewables post 1970. Data on renewables from the IEA accounts not only for biofuels and hydropower, but also includes waste, solar, wind and geothermal. Since solar, wind, geothermal and waste have only attained somewhat sizeable magnitudes in the last two decades or so, their pre-1971 omission should not have a sizeable impact on renewable energy consumption pre-1971.

\section{Residual Energy Consumption Variables, by Fuel}

To calculate residual consumption, by fuel, we undertake two steps to create $X_{\text {supp }}$. First, we use annual TPES (in ktoe) from IEA (2018c) which is available for most countries from 1971 onwards. ${ }^{36}$ Second, we backfill residual consumption, by fuel, with a combination of our other data sources, i.e., Fernandes et al. (2007), Mitchell (1992a, 1992b,1992c), TSP (2018), and UN (2016). For the fuels that rely on Mitchell and UN data only pre 1970, whether we take Mitchell first and then supplement with UN, or use UN data first and then supplement with Mitchell in the period between 1950 and 1970, differs by fuel and country, based on manual inspection of the data. Next, we describe these manipulations by fuel, and remind the reader that all TPES data post 1970 comes from IEA (2018c).

For coal, we use the IEA category "coal and coal products". We rely on Mitchell first and, if missing, use UN data for the period between 1950 and 1970.

To calculate oil TPES, we take the sum of two distinct IEA categories: (1) "Crude, NGL and feedstocks' and (2) "oil products". For the period 1950-1970 we rely on UN first (including two additional categories: withdrawals from marine bunkers and aviation bunkers) which

\footnotetext{
${ }^{34}$ To subsequently convert this variable to mtoe, we use a conversion factor of 0.0859845228 from the IEA (2018b).

${ }^{35}$ We used the following conversion coefficients [in megajoule per kilogram (MJ/kg)]: bagasse: 9.6 , animal dung: 15, dried plants: 10, fuelwood: 21, and charcoal: 30 .

${ }^{36}$ TPES is made up of production + imports - exports - international marine bunkers - international aviation bunkers \pm stock changes of primary energy. IEA, World Energy Balances 2019 Edition - Database Documentation, accessed: https://www.iea.org/subscribe-to-dataservices/world-energy-balances-and-statistics
} 
maintains consistency with the IEA data, and supplement with Mitchell, if UN data is missing.

For natural gas, we use data from the UN first and, if missing, supplement with Mitchell data to fill in the period 1950-1970.

For hydropower, we rely on TSP (2018) for the period from 1900 to $1970^{37}$.

For nuclear, we rely on EIA first, and then TSP (2018) for the period between 1950-1970.

For biofuels, we rely on Fernandes et al. (2007) for the period between 1850-1970.

For renewable energy, we sum biofuels from Fernandes et al. (2007) and any available hydropower data from TSP for the period 1850-1970.

\section{Final Aggregate Energy Consumption Variable}

Aggregate energy consumption is calculated as the sum of all primary energy fuels. We only report aggregate energy consumption if (1) both biofuels and coal are present before 1949, and (2) both biofuels and at least one other fuel are present after 1950. This prevents large changes in total consumption when fuels enter the dataset.

\section{Energy Prices}

For oil, coal, and natural gas prices, we use annual prices from the EIA, IMF Primary Commodity Price System (PCPS), and Rapidan Energy Group. We also use price series from Jacks (2019) that cover the period 1850-2015. Jacks' sources of nominal commodity prices include the annual Sauerbeck/ Statist series dating from 1850-1950, and the annual Grilli and Yang series dating from 1900-1986, amongst others. As PCPS prices start later in the $20^{\text {th }}$ century (1960s onward), we use a number of historical sources for earlier years.

\section{Coal}

From PCPS, we use two coal prices (1) Australia - Coal Newcastle 6000 kcal NAR fob prompt, London close, midpoint, fob, and (2) South Africa - Coal Richards Bay $6000 \mathrm{kcal}$ NAR fob prompt, London close, midpoint, fob. From EIA, we rely on US coal prices only. For our long price series, we use Jacks nominal prices to backfill this data.

\section{Oil}

From PCPS, we use three crude oil price benchmarks (1) Dated Brent, light blend 38 API, fob U.K., USD/bbl, (2) Dubai Fateh Fateh 32 API, USD/bbl and (3) West Texas Intermediate 40 API, Midland Texas, USD/bbl. For our long price series, we use data provided by Rapidan Energy Group, which starts in 1850.

\section{Natural Gas}

From PCPS, we use three natural gas prices (1) Natural Gas spot price at the Henry Hub terminal in Louisiana, USD/MMBtu, (2) LNG des Northeast Asia (ANEA) half-month 1, No time stamp, midpoint, delivered, USD/MMBtu, and (3) Netherlands TTF Natural Gas

\footnotetext{
${ }^{37}$ Brazil, Italy and the United States are the first countries for which we observe hydropower consumption, starting in 1900.
} 
Forward Day Ahead, EUR/MWh. For our long price series, we use Jacks (2013) to backfill this data.

All these prices are converted to dollar per ktoe and then deflated using the US CPI (Officer 2018). To calculate prices at the country level we take an unweighted average of the most relevant region prices. For example, for crude prices the North America region is assigned US crude oil prices from Rapidan Energy Group, while prices for countries in Europe and MENA regions are calculated as 50 percent Brent and 50 percent Dubai.

\section{Country-Level Aggregated Energy Price Indices}

We constructed an average energy price [in USD/Mtoe] for each country as the unweighted average of coal, crude oil and natural gas prices. To introduce cross-country variation post 1950 , we use real exchange rates to convert the average price to local currency units.

\section{Population and GDP per capita}

To measure population (in thousands at mid-year), and GDP per capita (in international GK\$), we rely on The Maddison Project from 1800 until 2016 (See Maddison Project Database, version 2018). The 2018 version of this database covers 169 countries. We supplement some years by using population provided by Mitchell, as well as other sources to fill in earlier years as necessary (please see Country Specific Data Sources).

\section{Land}

To measure land area, we use data from the WDI in square kilometers until 2018; since this data only starts in 1961, we hold land area fixed, and extend it backwards to fill in the earlier years.

\section{B3. Country Specific Data Sources}

We supplement our main data sources with a variety of historical data sources. Here we list them by country.

\section{Austria}

Coal output of Austria refers to that of Cisleithania from 1842-1918. From 1919 onwards, it refers to Republic of Austria. Population data 1842-1913 for Cisleithania is from Mitchell (1992b). Since biofuel consumption from Fernandes et al. (2007) is based on present-day borders rather than historical borders, we upscale the biofuel consumption data between 1842-1913 using Cisleithania population data from Mitchell.

\section{Hungary}

Production, consumption and net imports of coal (1851-1913) are taken from Gross (1971) and refer to Transleithania. Using population data from Mitchell (1992b), biofuel consumption is adjusted to match Transleithania's population between 1837-1913 rather than the population consistent with the borders of modern Hungary.

\section{$\boldsymbol{U S A}$}

Natural gas production (1885-1929) is taken from Schurr et al. (1960). 
Natural gas production (1930-1960) is taken from EIA (2019).

\section{USSR/Russia}

Population data for the USSR (1922-1939 and 1946-1949) is from Maddison (2018); for years (1940 and 1950-1990), it is from Mitchell (1992b). Population data for Russia (1800$1909)$ is from Mitchell (1992b) and (1991-2018) it is from Maddison (2018). 
Table Appendix B.1: Median and Mode

\begin{tabular}{|c|c|c|c|c|c|c|c|c|c|}
\hline & & (1) & $(2)$ & (3) & $(4)$ & $(5)$ & (6) & $(7)$ & $(8)$ \\
\hline \multirow{2}{*}{ Dynamic Saturation Point } & Median & - & 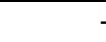 & 42,714 & 42,845 & 72,281 & 90,146 & 29,550 & 53,117 \\
\hline & Mode & & & 35,928 & 35,928 & 53,629 & 62,480 & 27,078 & 44,779 \\
\hline \multirow{2}{*}{ Static Saturation Point } & Median & - & - & 106,530 & 107,380 & 211,900 & 211,900 & 41,329 & 65,502 \\
\hline & Mode & & & 84,768 & 84,768 & 147,920 & 147,920 & 21,617 & 42,668 \\
\hline \multirow{2}{*}{ Graduation from Biomass } & Median & - & - & 904 & 904 & 952 & 952 & 1,069 & 996 \\
\hline & Mode & & & 927 & 942 & 973 & 973 & 1,066 & 1,020 \\
\hline \multirow{2}{*}{ Max Elasticity } & Median & 0.8994 & 0.9299 & 1.0531 & 1.0521 & 1.0519 & 1.0519 & 0.8265 & 0.6311 \\
\hline & Mode & 0.8913 & 0.9220 & 1.0450 & 1.0604 & 1.0450 & 1.0450 & 0.7990 & 0.6145 \\
\hline \multirow{2}{*}{ Inflection Point } & Median & - & . & 9,817 & 9,854 & 14,221 & 14,221 & 6,645 & 8,063 \\
\hline & Mode & & & 8,455 & 9,653 & 12,051 & 12,051 & 6,057 & 7,256 \\
\hline
\end{tabular}

Note: Based on Monte Carlo simulation of 100,000 samples. [] represent 10th and 90th percentile confidence intervals, repsectively. For the description of the specifications see Table 1 


\section{Cyclical Movements in Energy Efficiency}

Cyclical movements in energy savings are strongly related to the global business cycle and oil price movements - proxying for energy prices. The aftermaths of oil price shocks of the 70s and consequent US recessions led to cyclical energy savings (in 1974 and 1980-83). Cyclical energy savings raise above zero in 1988 two year after the counter oil shock (i.e., the breakdown of OPEC). Cyclical forces slowing down energy savings peaked temporarily in 1999 as oil prices troughed. In the mid-2000s the China growth spur was initially energy intensive leading to a global increase in energy demand. The cyclical energy efficiency component peaked in 2004 . The consequent rise in energy price and, later, a slowdown in global growth induced a reduction in energy demand.

We test formally the role of oil prices and global growth by estimating the response of the cyclical energy efficiency component to oil price and global growth shocks. ${ }^{38}$ A one standard deviation shock to oil prices, which raises oil price by 29 percent, decreases energy demand by about 0.5 percent in the second year and about 1.2 percent after 8 years. A one standard deviation increase in global GDP, by about 1.5 percent, leads to an increases in energy demand by about 0.7 percent, but estimates are imprecise. ${ }^{39}$

Figure Appendix C.1

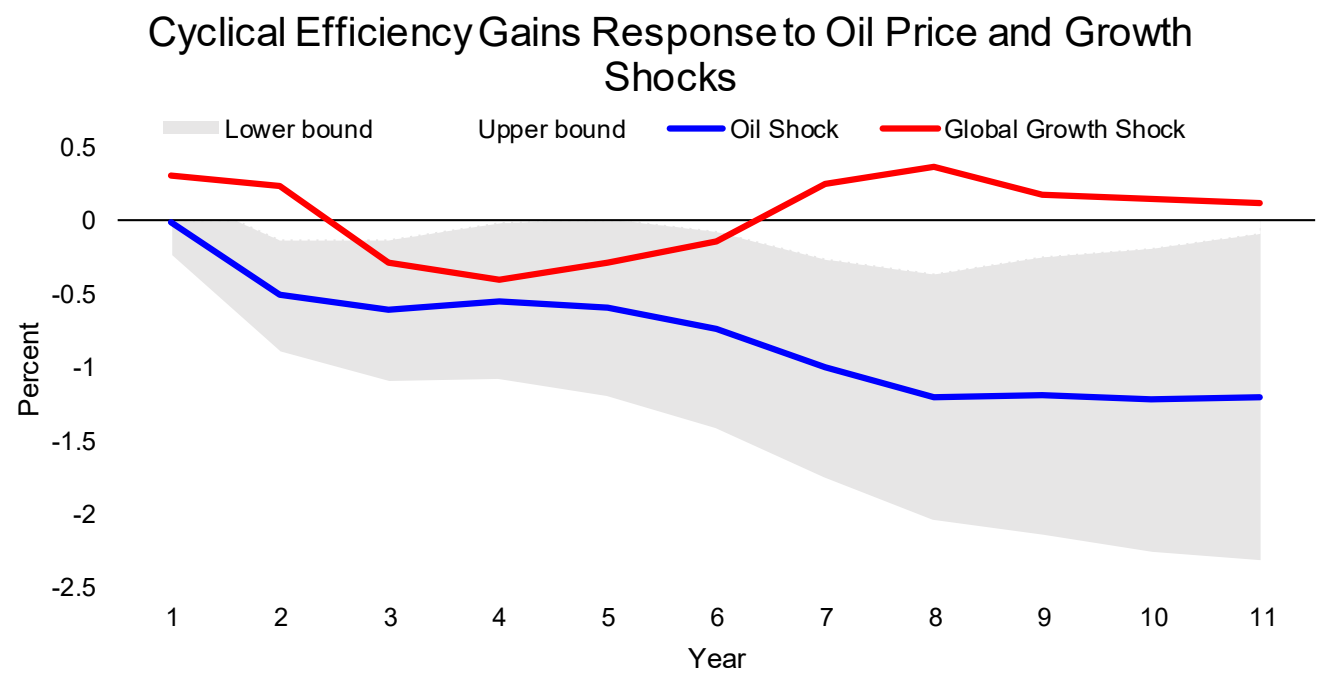

Source: Energy Demand Dataset

Note: Global GDP is the log of the sum of PPP GDP for all the countries in the baseline panel regression of Table 1. Real oil prices are in logs and deflated US CPI. A linear trend is added to the trivariate VAR where GDP and oil prices are ordered first and second, respectively. Local projections methods are us ed to es timate the VAR.

\footnotetext{
${ }^{38}$ Global GDP is the log of the sum of PPP GDP for all the countries in the baseline panel regression of Table 2. Real oil prices are in logs and deflated US CPI. A linear trend is added to the trivariate VAR where GDP and oil prices are ordered first and second, respectively. Local projections methods are used to estimate the VAR.

${ }^{39}$ The cross-correlation between (real) oil prices and deviations from the efficiency trends is below -0.5 , with oil prices leading by 3 to 5 years.
} 